\title{
Kırsalda ve Kentte Yaşayan Kadınların Aile Değerlerinin Karşılaştırılması
}

\section{Comparison of Family Values of Women Living in Rural and Urban Areas}

\author{
Arzu ÖZYÜREK, Prof. Dr. \\ Karabük Üniversitesi, Sağlık Bilimleri Fakültesi, Karabük / Türkiye. \\ a.ozyurek@karabuk.edu.tr \\ https:// orcid.org/0000-0002-3083-7202
}

Ayşenur AYDIN, Sorumlu Yazar, Uzman.

Karabük Ünversitesi, Karabük / Türkiye.

aydn.aysenr@gmail.com

https://orcid.org/0000-0001-6217-4135

ISSN: 1303-880X

e-ISSN: 2667-7504

http://ded.dem.org.tr

Makale Türü / Article Type:

Araştırma Makalesi / Research Article

Geliş Tarihi / Received Date: 07.04.2021

Kabul Tarihi / Accepted Date: 11.06.2021

Yayın Tarihi / Published Date: 25.06.2021

Tr/En: $\mathrm{Tr}$
Atıf/Citation: Özyürek, A. \& Aydın, A. (2021). Kırsalda ve kentte yaşayan kadınların aile değerlerinin karşılaştırılması. Değerler Eğitimi Dergisi, 19 (41), s.313-349. https://doi.org/10.34234/ded.899968 
Öz: Bu çalışmada, kırsalda ve kent merkezinde ikamet eden evli kadınların aile değerlerinin kişisel bazı değişkenlere göre incelenmesi amaçlanmıştır. Çalışma grubunu, kırsalda ikamet eden 60 ve şehir merkezinde ikamet eden 84 kadın olmak üzere toplam 144 evli kadın oluşturmuştur. Verilerin toplanmasında Aile Değerleri Ölçeği kullanılmıştır. Veriler, kırsaldaki kadınlardan bireysel görüşme yoluyla, şehir merkezindeki kadınlardan çevrimiçi katılım yoluyla toplanmıştır. Verilerin analizinde normallik dağılımı dikkate alınarak Mann Whitney U ve Kruskal Wallis $\mathrm{H}$ testleri ile Spearman Brown Korelasyon katsayısından yararlanılmıştır. Sonuç olarak; kırsalda yaşayan kadınların kentte yaşayanlara göre daha fazla oranda aileyi geleneksel olarak değerlendirdikleri, çocuk bakımında anneye önem atfettikleri, çocuk yetiştirme rolüne önem verdikleri, ailede demokratik katılım olması gerektiğini düşündükleri, ailenin sosyal ve ekonomik bir yapı olarak algıladıkları, akraba ilişkilerine önem verdikleri ve geniş aileye olumlu baktıkları belirlenmiştir. Kentte yaşayan kadınların kırsalda yaşayanlara göre daha fazla cinsellikle ilgili konularda serbestlikten yana oldukları, konvansiyonel olmayan değerleri önemsedikleri, eşler arası sadakate önem verdikleri ve aile saadeti için şiddeti meşru gördükleri belirlenmiştir. Kadınların çalışıp çalışmama durumu, yaşı, öğrenim durumu, evlilik süresi ve çocuk sayısı ile aile değerlerine bakışları arasında anlamlı farklılıklar belirlenmiştir.

Anahtar Kelimeler: Aile, Aile değerleri, Kırsal, Kadınlar.

\section{Comparison of Family Values of Women Living in Rural and Urban}

\section{Areas}

Abstract: In this study, it is aimed to examine the family values of married women residing in the countryside and the city center by comparing them according to some personal variables. The working group consisted of a total of 144 married women, including 60 rural residents and 80 women residing in the city center. Family Values Scale was used to collect the data. The data was collected from rural women through individual interviews and through online participation from women in the city center. Mann Whitney U and Kruskal Wallis H tests and Spearman Brown Correlation coefficient were used in the analysis of the data taking into account the distribution of normality. As a result; women living in the countryside traditionally rated the family at a higher rate than those living in the city, they attach importance to the mother in child care, they attach importance to the role of raising children, they think that there should be democratic participation in the family, it has been determined that the family perceives it as 
a social and economic structure, attaches importance to relative relations and looks positively at the extended family. It has been determined that women living in the city are more in favor of freedom in matters related to sexuality than those living in the countryside, care about non-conventional values, care about spouse loyalty and consider violence legitimate for family bliss. Significant differences were identified between whether women worked, age, education status, duration of marriage and number of children and their view of family values.

Keywords: Family, Family values, Rural, Women.

\section{Giriş}

Birey yaradılışının kendisine yüklediği özellikler gereği, ait olma ihtiyacıyla doğan sosyal bir varlıktır. Bireyin yaşamını sağlıklı bir şekilde sürdürebilmesi için ihtiyaçlarının giderilmesi gerekir. Bireyin beslenme, barınma, giyinme vb. fizyolojik ihtiyaçlarından sonra kendisini ifade edebilmeye, biricik ve önemli olduğunu hissetmeye, güce, samimiliğe ve anlamlı olduğunu bilmeye ihtiyacı vardır. Bireyin eğitiminin, sağlığının, ekonomik hayatının vb. zeminini oluşturan aile, bu ihtiyaçların karşılanmasında önemli bir rol üstlenmektedir (Arda, 2018). Aile evlilikle birlikte eşler, çocuklar ve kardeşlerin kendi aralarındaki ilişkilerin temelinin atıldığ nımlanır (TDK, 2020). İnsanlıkla birlikte var olan ve toplumun temel taşı olarak nitelendirilen aile kurumu, bireyin beğenildiği, kendini ait hissettiği, sevildiği, sosyal ve ekonomik güvenliğinin sağlandığı, beslendiği ve barındığı bir yuvadır (Kır, 2011). Türkiye Cumhuriyeti Anayasası 41. maddesinde aile "Aile, Türk toplumunun temelidir ve eşler arasında eşitliğe dayanır. Devlet, ailenin huzur ve refahı ile özellikle ananın ve çocukların korunması ve aile planlamasının öğretimi ile uygulanmasını sağlamak için gerekli tedbirleri alır, teşkilatı kurar" (Türkiye Cumhuriyeti Anayasası, 1982) şeklinde tanımlanmaktadır. Aile, insan türünün ve toplumsal yaşamın devamlılığını sağlayan değer ve davranış biçimlerini, maddi ve manevi zenginlikleri nesilden nesile aktaran, sosyokültürel, biyolojik, sosyodemografik, psikolojik, hukuki, ekonomik gibi yönleri bulunan toplumdaki en önemli analiz kurumlarından biridir (Yapıcı, 2010; Aktaş, 2015). Aile bireyin yetişkin olarak cinsiyet rollerini benimsedikleri, aile içerisinde yaşanan farklı deneyimlerle gelecekteki evlilik beklentilerinin şekillendiği bireyin sosyalleşme adımlarının da atıldığı kurumdur (Dillon, 2005).

Ailenin zaman içerisinde işlevinde çeşitli farklılaşmalar olsa da mevcut toplumsal yapıların oluşması ve şekillenmesinde, en büyük katk1 ailenindir. Ge- 
niş aile zamanla küçülerek çekirdek aileye indirgenmiş, aile kurumu meslek edindirme, yönlendirme ve eğitim gibi çeşitli alanlardaki rollerini başka kurumlara bırakmış olsa da çocuk sahibi olma, koruma, yetiştirme, kişisel gelişimi destekleme, büyütme gibi işlevlerini özenle sürdürmeye devam etmektedir. (Kır, 2011). Toplumun temeli aile iken toplumlar, genellikle var olabilmek ve bu varlığı sürdürebilmek için değerlere ihtiyaç duyarlar. Genel anlamda değer herhangi bir şeyin önemli olma durumunu ifade etmeye yarayan bir soyut ölçü, sahip olduğu yüksek ve yararlı kıymet biçiminde tanımlanabilir. Çoğu insan tarafından paylaşılan ve uzlaşılan gerçek olan davranış ölçüsüdür (Kızıler ve Canikli, 2013). Değerleri birbirinden ayıran önemli özellik, değerlerin yönü, ifade ettikleri hedefin türüdür. Değerler, genel anlamda, bireyin yaşamında yol gösterici prensipler olarak fayda sağlayan, önemi değişen, istenilen, dönüşümsel hedefler olarak ifade edilir (Struch, Schwartz ve Van Der Kloot, 2002). Değerler toplumsal kültürü özgünleştirerek diğer toplumların kültürlerinden ayırır ve bu ayrımın süreklilik kazanmasını sağlar. Bu özelliğiyle toplumların milli sınırları içerisinde, bireyler arası sosyal dayanışmayı sağlayarak birliklerini pekiştiren ve dağılmasını önleyen önemli faktör olma özelliği taşırlar (Yazıc1, 2014) Değerler çoğu zaman değiş̧ime karşı bir direnç gösterseler de değişen zaman dilimlerinde kültürün değişmesiyle birlikte değerlerde de bir değişme görülmektedir (Bolat, 2016). Fakat değerler yalnızca kültürel değişmelerden etkilenmez. Dolaylı olarak yaş, cinsiyet ve eğitim seviyesi gibi faktörler de değerleri etkiler (Arends-Tóth ve Van de Vijver, 2009). Bireylerin değer öncelikleri, dünyaya bakış açılarının bir parçasıdır. Erkekler ve kadınlar farklı bakış açıları geliştirdikçe değerlerin önceliklerinde de farkl1lıklar görülmesi beklenebilir (Struch, Schwartz \& Van Der Kloot, 2002). Bireyin demografik özelliklerinin ve kültürel değişmelerin yanı sıra deneyimleri, sosyal rolleri, yetenekleri ve beklentileri gibi durumları içeren yaşam koşulları bireyin hayatını sahip olduğu değerleri büyük ölçüde belirler. Dolayısıyla bireyin değer oluşumunda arka planda yatan en önemli etken yaşam koşullarıdır (Schwartz, 2006). Mesleki, toplumsal, kişisel, cinsellik gibi kimlik yapılarını içine alan, sosyal rollerle öğrenilen ve genetik olarak aktarılmayan değerler, bireyin düşünce ve tercihleriyle öğrendiği her yeni bilgiyle yeniden şekillenmektedir. Şekillenen bu değerler kuşaktan kuşağa aktarılır. Değerlerin öğrenildiği bu sosyal rollerde bireyin neleri yapıp yapmaması, neleri önemsemesi gerektiği öğrenilir ve bazen bunlar yaptırım olarak da ortaya çıkabilir (Aktepe ve Yel, 2009).

Sanayinin ilerlemesiyle tarım hayatından sanayi hayatına geçiş yapılmasının ardından geleneksel aile yapısından modern aile yapısına geçişte değer kavra- 
mının anlamında da değişiklikler olmuştur. Toplumların sürekliliğini sağlayan, sosyal denetimine kaynaklık eden, onları ayakta tutan ve toplumların gelişmesini destekleyen değerler bireysel, yönlendirici ve koruyucu fonksiyonlara sahiptir (Duman, 2016). Değerler bireysel değerler, toplumsal değerler ve aile değerleri şeklinde sınıflandırılabilmektedir (Akbaba Altun, 2003). 2010). Aile değerleri genel olarak var olan değerlerin bir alt kolu ya da yansıması olarak kabul edilebilir. Bu değerler zaman içerisinde kültürel, ekonomik ve politik olan gelişmelere göre değişebilir. Dolayısıyla aile değerleri de toplumdan topluma, kuşaktan kuşağa değişiklik gösterebilir. Değerler paylaşılabilir ve nesilden nesile aktarılırken insan etkileşiminin ürünü olmasından dolayı sürdürülebilir ve değişimler yaşanabilir (Ekşi ve diğerleri, 2015). Kendisine verilen roller ve işlevleriyle toplumların önemli kurumu olan, geçmişten bugüne çoğu toplumun özelliğini, o toplumda bulunan bireylerin görevlerini, değer yargılarını, tercihlerini, inançlarını içerisinde toplayan, toplumların değer ve düşünce sisteminin aktarılmasını ve nesiller arası bağın devamlılı̆̆ında köprü konumunda olan aile, kendine özgü değerlere de sahiptir (ASAGEM, 2010). Aile değerleri giderek güçlenmekte ve ebeveynler çocuklarına aile değerlerini öğretmen için her zamankinden daha çok çaba sarf etmektedirler (spokanecares.org, 2021).

Aile değerleri kapsamında geleneksel aile değerleri, cinselliğe bakış, anne-çocuk ilişkisi, çocuğun değeri, karar alma süreçleri, evliliğe bakış, kadının rolü, farklı yaklaşımlar, sosyo- ekonomik değer, akraba ilişkileri, duygusal bağ ve aile içi şiddet ele alınabilir (Ekşi vd., 2010). Geleneksel aile değerleri, geleneksel toplumsal dönemde varlığını sürdüren dönemin tarımsal üretim biçiminden, tarihsel koşulundan ve inanışlarından etkilenen geleneksel aileyi dolayısıyla geleneksel ailenin benimsediği değeri ifade eder. Geleneksel aile genellikle geniş, akrabalık ilişkileri kuvvetli, mahrem ve çok işlevli toplumsal bir yapıyı çağrıştırır. Genellikle bu ailelerde ataerkil bir yapı mevcuttur (Özkiraz, Arslanel ve Şengül, 2016). Aile gelenekçiliği, muhafazakâr ve eskiden süre gelen cinsiyet rolleri beklentilerinin yaşam normlarına bağl1lığını vurgular ve çoğu zaman değişime karşı direnç gösterir (Castro, Stein ve Bentler, 2009). Cinselliğe bakış, bireyin büyüyüp yetiştiği ailesinden, çevresinden, içinde bulunduğu toplumun yapısından, gelenek ve göreneklerinden, cinsel, ahlaki tutum ve davranışlarından, dini inanışlarından etkilenir (Bozdemir ve Özcan, 2011). Cinselliğin zor bir konu olarak algılandığı toplumumuzda cinsellikle ilgili düşüncelerin ifade edilmek istenmediği düşünülse de aslında kadınların cinsel yaşamlarına dair sağlık görevlerini bilgilendirmeye ve varsa cinsel sorunları hakkında çözümler bulmaya hazır oldukları belirtilmektedir (Kömürcü ve diğerleri, 
2014). Ailede anne-çocuk ilişkisiyle birlikte, çocuk için ilk sosyal davranışlar ailede kazanılır. Bu da ailedeki bireyler arasında gerçekleşen etkileşim sonucu oluşur. Çocuğun ailesindeki yerini, anne-baba başta olmak üzere ailedeki bütün bireylerin çocukla kuracağ etkileşim belirler. Aile, çocuğun güven duygusunu edinmesini ve sosyal açıdan kişilerarası kabul görebilmesi için uygun ortam hazırlar. Anne-çocuk etkileşiminde ilk sosyal ilişkilerin devamlılığını sağlamak için oldukça önemlidir. Çocuk ve annesi arasında gerçekleşen sağlıklı etkileşim, onun kişiliğinin sağliklı gelişmesine önemli bir şekilde etki eder. Aile dışındaki bireylerle daha olumlu bir iletişim gerçekleştirmesinin temelini oluşturur (Kandır ve Alpan, 2008). Ailede çocuğun değeri, anne ve babanın çocuk sahibi olmalariyla birlikte elde ettikleri sosyal, ekonomik ve psikolojik faydalar olarak açıklanabilir (Erol ve Aloğlu, 2017). Yetişkin bireylerin çocuktan üstlenmesini istediği roller ve çocuğa yükledikleri anlam tarihsel süreçlere, içinde bulunulan toplumun kültürüne göre değişiklik göstermiş, çocuğa karşı zaman zaman farklı yaklaşımlarla davranılmıştır. Toplumlarda teknolojik, sağlık ve eğitim alanında gerçekleşen ilerlemeler bulaşıcı birçok hastalığa karşı önlem, teşhis ve tedavi uygulamaları hızlandırılmış çocuğun ölüm riski azalmış ve çocuğa verilen değer artmıştır (Erkut, Balcı ve Yıldız, 2017).

Aile değerleri kapsamında ele alınabilen karar alma süreçleri, aile içerisinde karar alınması gereken bir konuda karar alma sürecinin demokratik, katılımcı ya da aile büyüklerinden birinin görüşleri doğrultusunda belirginleştiğini belirtmektedir. Türk kültüründe uzun zaman boyunca geniş aile özelliği hâkim olmakla birlikte çoğu zaman ailede babanın sözü daha baskın olup ve onun fikirleri dikkate alınarak hareket edilmektedir. Fakat son y1llarda ailelerin karar olma süreçlerinin daha demokratik olarak gerçekleştiği görülmektedir (Arda, 2018). Aile değeri olarak evliliğe bakış açısı özellikle nüfus sağlığı açısından evliliğin önemli bir sosyal durum olduğunu kabul etmeyi kapsar (Hayward ve Zhang, 2006). Bireyin yaşamına birçok yönden etki eden evlilik, kişiye yaşattığ zorluklar, sevinçler, mutluluklar ve yararlarıyla insanların çoğunluğu tarafindan ulaşılması istenen bir amaçtır (Çağ ve Yıldırım, 2013). Ailede kadının rolü, önemli bir diğer değerdir. Toplum tarafından bireye kadın, erkek, anne, baba, ebeveyn, eş, çocuk, egemen olan veya boyun eğen olarak yüklenen toplumsal roller vardır (Çakmak, 2009). Opprang ve Apu (1985) kadının annelik, ev kadınlığı, akrabalık, eşlik, bireylik, topluluk ve mesleki rolleri olduğunu belirtmişlerdir. Annelik rolü, kadının kendi çocuğunu büyütmesi ve toplumsal hayata hazırlamasıyla alakalıdır ve kadından anneliğin yüklediği rolü en iyi biçimde gerçekleştirmesi beklenir. Eşlik rolü, kadının eşine karşı üstlendiği rol ve ev 
kadınlığı rolü, kadının evlenmemiş olsa dahi evde evle ilgili durumlarda üstlendiği roldür. Akrabalık rolü kadının akrabalık ilişkilerinde üstlendiği rollerin bütünüdür. Aile ve akrabalık bağlarının daha katı olduğu toplumlarda akrabalık rolüne ilişkin beklentiler de daha katıdır. Mesleki rol, kadının ekonomik bir etkinliğe katılımıyla gelir elde eder duruma gelmesiyle ortaya çıkmış, kadının aile yaşantısı ve evi dışında ayrı bir sosyal çevrede üstlendiği roldür. Topluluk rolü, kadının içinde bulunduğu ailesinden ve yaşadığı meslek ortamından ayrı dışarda kalan alanlardaki üstlendiği roldür. Bireylik rolü kadının kişisel gelişiminde, dünyada mevcut ve değişen olaylarda dahil olma sürecinde gösterdiği davranışlardır. Dolayısıyla kadının birey olarak kendini ifade etmesinde üstlendiği roldür (Akt.: Gönüllü ve İçli, 2001).

Aile değerleri açısından farklı yaklaşımlar, aile kurumu ve evliliğin sadece çocuk anne ve babadan ibaret olmadığ dığında da aile olunabileceği vb. yaklaşımları ifade eder (Kara, 2018). Sosyo-ekonomik değerde üretim, değişim, dağıtım ve tüketim ekonominin dört temel unsurudur. Kişi üretim ve tüketim için gerekli olan bilgi ve kabiliyetlerin ön aşamasını ailede gerçekleştirmektedir (Kır, 2011). Kadınların iş hayatına katılımıyla birlikte ailenin ekonomik kaynakları büyük oranda gelişmiş ve bu doğrultuda gelirin kullanım şeklinde değişiklikler görülmüştür (Arpacı ve Ersoy, 2007). Akraba ilişkileri, biyolojik temelli olmasına karşın toplumun sahip olduğu kültür, akraba ilişkilerini belirlemekte ve sosyal ilişkiler ağına öncülük etmektedir. Bu özelliğiyle kavram olarak akraba ilişkileri evrensel bir özelliğe sahiptir. Fakat buna rağmen akrabalık ilişkileri toplumlar arası değişiklik göstermektir. Bu değişiklik toplumların kendilerine ait akrabalık sisteminin belirlenmesine neden olmaktadır (Tutar, 2007). Evliliğin temelinde duygusal bağ bulunmaktadır ve evlilik aşkı, mahremiyeti, sevgiyi ve bağlanmayı içine alan bir yap1, sadakat içten bağl11ı (TDK, 2020) ve sadakatsizlik bağlı olma sözü verilen bir ilişkide çiftin birbiri dışında kendi ilişkilerine zar verecek her türlü davranış, fikir ve duygu olarak tanımlanmaktadır (Tüzer, 2011). Dolayısıyla aile, aile içerisindeki bireylerin paylaştığı güçlü duygusal bağll1ık nedeniyle duygusal bir yaşam ortamıdır. Çoğu ailenin yaşadığı duygusal bağlar vardır ve bu bağlar kişin sahip olduğu değerlere, inançlara, davranışlarına ve duygularına ciddi bir şekilde etki eder. Aile içerisindeki bireyler birbirlerine destek, onay, ihtiyaçlarına ve beklentilerine karşılık verir ya da birbirlerinden karşıllık beklerler (Dillon, 2005). Aile içinde şiddet ise eşlerin birbirlerine karş1lıklı şiddette bulunmalarını, bazen çocuğun bu şiddete tanık olması veya maruz kalmasını, aile fertleri arasındaki ilişkilerde bozulmaları, ailenin dağılışını, ailenin temel 
işlevlerini yerine getiremediğini ifade edebilir. Şiddet aileyi, toplumu dolayısıyla değerleri tehdit etmektedir (ASAGEM, 2010).

Aileyi oluşturan unsurlardan biri kadındır ve kadınların toplumda sosyal hayatın her aşamasında önemli rolleri bulunmaktadır. Fakat sahip olunan rol ve statüleri çeşitli nedenlerle değişikliğe uğramaktadır (Albayrak, 2017). Kırsal ve kentte ikamet ediyor olmak bu durumu etkileyen etmenlerden biri olabilir. Kirsal alanda yaşayan kadınların büyük çoğunluğu tarımda çalışmakta, kimi zaman yaptıkları işler veya ürettikleri görmezden gelinmektedir. Kırsal alanda yaşayan kadınlar yasalar karşısında kentte yaşayanlarla eşit haklara sahip olmalarına rağmen öğrenim düzeyinin düşüklüğü veya ekonomik bağımsızlıklarının olmaması gibi nedenlerle kentte yaşayanlara göre daha fazla ezildikleri söylenebilir. Kentlerde eğitim ve işgücüne katılım daha fazladır. Kırsalda ataerkil aile yapısı daha güçlüdür, evlilik yaşı ve boşanma düzeyi daha düşüktür (Arıkan, 1988). Kırsal ve kentte kadının aile içinde veya toplumdaki rolü ve statüsü gerek yaşam şartları gerekse eğitim ve sağlık gibi hizmetlere ulaşım imkanlarının farklılaşması vb. durumlarla yakından ilişkilidir. Ailede kadına verilen değer ile kadınların aile değerlerinin de bu durumdan etkilendiği söylenebilir.

Aile değerlerini konu alan çalışmalar incelendiğinde, Türkiye Cumhuriyeti Aile ve Sosyal Araştırmalar Genel Müdürlüğü (2010) tarafından medya profesyonellerinin ve medyanın aile algısı araştırması, öğrencilerin aileleri ve aile değerleri (Demir ve Kök, 2012), üniversitede öğrenim gören kız öğrencilerin cinsiyet rolü tutumları bağlamında aile ve evlilik kurumlarına bakışları (Akın ve Aydemir, 2007), Almanya'da yaşamını sürdüren Türklerin aile değerleri (Ekşi vd., 2015), üniversite öğrencilerinin aile kurumuna bakışı (Özkiraz vd, 2016), aile değerlerinin alkol kullanımına etkisi (Arda, 2018), yetişkinlerin aile değerleri (Özyürek vd., 2019), aile değerleri ile aile yılmazlığı arasındaki ilişkinin incelenmesi (Yazıcı, 2019) Kırsal ve kentsel evliliklerle ilgili politika çıkarımları (Scanzoni ve Arnett, 1987) üniversite öğrencilerinin kişilik özellikleri ile aile değerleri arasındaki ilişkinin incelenmesi (Polat, 2020) gibi çalışmalar olduğu görülmüştür. Bu çalışmalarda farklı çalışma gruplarının aile değerlerine bakışı veya aile değerleriyle ilgili bazı değişkenler ele alınmıştır. Bu çalışmada ise, kırsalda ve kent merkezinde ikamet eden evli kadınların aile değerlerinin kişisel bazı değişkenlere göre karşılaştırılarak incelenmesi amaçlanmıştır.

Çalışmada aşağıdaki sorulara cevap aranmıştır:

- Kırsalda ve kentte yaşayan kadınların aile değerlerinde yaş, öğrenim durumu ve çalışma durumuna göre fark var mıdır? 
- Kırsalda ve kentte yaşayan kadınların aile değerlerinde evlilik süresi ve çocuk sayısına göre fark var mıdır?

\section{Yöntem}

\section{Araştırma Modeli}

Çalışma nicel olarak tasarlanmıştır. Çalışmada annelerin mevcut aile değerlerine bakış açısı var olduğu haliyle belirlenmeye çalışıldığından betimsel tarama modelindedir (Sönmez ve Alacapınar, 2011).

\section{Çalışma Grubu}

Çalı̧̧ma grubunu, kolay ulaşılabilir örnekleme yöntemiyle kendilerine ulaşı1labilen köyde ikamet eden 60 ve şehir merkezinde ikamet eden 84 kadın olmak üzere toplam 144 evli kadın oluşturmuştur. Çalışma grubuna dahil edilmede kadınların köyde veya şehir merkezinde ikamet ediyor olması kriter alınmıştır. Tümü gelir düzeyini orta olarak belirten çalışma grubuna ait bazı kişisel bilgiler Tablo 1'de sunulmuştur.

\begin{tabular}{|c|c|c|c|c|c|c|c|}
\hline & & \multicolumn{2}{|c|}{ Kırsal } & \multicolumn{2}{|c|}{ Kent } & \multicolumn{2}{|c|}{ Toplam } \\
\hline & & $\mathrm{f}$ & $\%$ & $\mathrm{f}$ & $\%$ & $\mathrm{f}$ & $\%$ \\
\hline \multirow[t]{3}{*}{ Yaş } & 30 yaş ve altı & 8 & 13,3 & 84 & 100,0 & 92 & 63,9 \\
\hline & $31-40$ yaş & 36 & 60,0 & - & - & 36 & 25,0 \\
\hline & $41-50$ yaş & 16 & 26,7 & - & - & 16 & 11,1 \\
\hline \multirow{5}{*}{$\begin{array}{l}\text { Öğrenim } \\
\text { Durumu }\end{array}$} & İlkokul & 44 & 73,3 & - & 7,1 & 44 & 30,6 \\
\hline & Ortaokul & 9 & 15,0 & 6 & 29,8 & 15 & 10,4 \\
\hline & Lise & 4 & 6,7 & 25 & 28,6 & 29 & 20,1 \\
\hline & Ön lisans & 2 & 3,3 & 24 & 34,5 & 26 & 18,1 \\
\hline & Lisans & 1 & 1,7 & 29 & 7,1 & 30 & 20,8 \\
\hline \multirow{2}{*}{$\begin{array}{l}\text { Çalışma } \\
\text { Durumu }\end{array}$} & Çalışmiyor & 60 & 100,0 & 41 & 48,8 & 101 & 70,1 \\
\hline & Çalışıyor & - & - & 43 & 51,2 & 43 & 29,9 \\
\hline \multirow{3}{*}{$\begin{array}{l}\text { Evlilik } \\
\text { süresi/yılı }\end{array}$} & $1-10$ y1l & 11 & 18,3 & 84 & 100,0 & 95 & 66,0 \\
\hline & $11-20$ y1l & 37 & 61,7 & - & - & 37 & 25,7 \\
\hline & 21 ve üzeri & 12 & 20,0 & - & - & 12 & 8,3 \\
\hline \multirow[t]{4}{*}{ Çocuk Sayısı } & Yok & - & - & 7 & 8,3 & 7 & 4,9 \\
\hline & Tek çocuk & 2 & 3,3 & 19 & 22,6 & 21 & 14,6 \\
\hline & İki çocuk & 31 & 51,7 & 42 & 50,0 & 73 & 50,7 \\
\hline & Üç ve üzeri & 27 & 45,0 & 16 & 19,0 & 43 & 29,9 \\
\hline
\end{tabular}


Tablo 1'e göre çalışma grubundaki kırsal kesimde yaşayan kadınların \%60'1 31-40 yaşlarında, \%26,7'si 41-51 yaşlarında; \%73,3'ü ilkokul mezunu ve tümü ev hanımıdır; \%61,7'si 11-20 y1l, \%20'si 21 yıl ve daha uzun süredir evlidir; $\% 51,7$ 'si iki çocuk ve \%45'i üç ve üzeri çocuk sahibidir. Çalışma grubundaki kentte yaşayan kadınların tümü 30 yaş ve altında; $\% 7,1$ 'i ilkokul, $\% 29,8$ 'i ortaokul, \%28,6'sı lise, \%34,5'i ön lisans, \%7,1'i lisans mezunu; \%51,2'si çalışan ve tümü 1-10 yıllık evlidir; \%22,6's1 tek çocuk, \%50'si iki çocuk ve \%19'u üç ve daha fazla çok sahibidir. Toplamda çalışma grubundaki kadınların \%63,9'u 30 yaş ve altında, $\% 20,1$ 'i lise ve $\% 20,8$ 'i lisans mezunu, $\% 70,1$ 'i ev hanımı, \%66's1 1-10 yıllık evli ve \%50,7'si iki çocuğa sahiptir.

\section{Veri Toplama Araçları}

Verilerin toplanmasında araştırmacılar tarafından oluşturulan ve katılımcıların ikamet ettiği yer, yaşı, öğrenim durumu, çalışma durumu, evlilik süresi/yılı ve çocuk sayısına yönelik bilgiler sorgulandığı Kişisel Bilgi Formu; aile değerlerinin belirlenmesinde Aile Değerleri Ölçeği kullanılmıştır.

Aile Değerleri Ölçeği, Ekşi ve arkadaşları (2010) tarafından geliştirilmiştir. Toplam 59 madde ve 13 alt boyuttan oluşan ölçek Kesinlikle Katılmıyorum (1 puan), Katılmıorum (2 puan), Kararsızım (3 puan), Katıliyorum (4 puan) ve Kesinlikle Katılıyorum (5 puan) şeklinde beşli likert tipindeki ölçekte 20 madde tersine puanlanmaktadır. Ölçek geliştirme işlemleri 18-52 yaş arası 313 kişiyle gerçekleştirilmiştir. Geleneksel Aile Değerleri (GAD) alt boyutu (5 madde) ailenin geleneksel olarak değerlendirildiğini, Cinselliğe Bakış (CB) alt boyutu (5 madde) cinsellikle ilgili konularda daha fazla serbestlikten yana olma, $A n$ ne-Çocuk Illişkisi (AÇ) alt boyutu (5 madde) çocuk bakımı hususunda anneye atfedilen önemi ve güçlü anne-çocuk bağlantısı olması gerektiğini, Çocuğun Değeri (ÇD) alt boyutu (5 madde) ailede çocuk yetiştirme rolüne daha fazla önem verilmesi gerektiği şeklinde yorumlanmaktadır. Karar Alma Süreçleri $(K A S)$ alt boyutu (5 madde) ailede karar alma sürecinin demokratik/katılımc1 olması gerektiği, Evliliğe Bakış (EB) alt boyutu (5 madde) evlilik ve evlilik kurumuna verilen önemi, Kadın Rolleri (KR) alt boyutu (5 madde) kadının konvansiyonel bakış açısı ile değerlendirildiğini göstermektedir. Farklı Yaklaşımlar (FY) alt boyutu (5 madde) konvansiyonel olmayan değerlerin daha fazla benimsendiği, Sosyo-Ekonomik Değer (EkD) alt boyutu (5 madde) ailenin daha çok sosyal ve ekonomik bir yapı olarak algılanması eğilimi, Kariyer alt boyutu, kariyer merkezli yaşantıların tercih edildiği şeklinde yorumlanmaktadır. Akraba 
Illişkiler $(A k \dot{I}) i$ alt boyutu (5 madde) akraba ilişsilerine önem verilmesi ve geniş aileye ilişkin olumlu bakışı, Duygusal Băg (DuB) alt boyutu (4 madde) aileye duygusal bağlılı̆̆ın arttığı, Sadakat (SAD) alt boyutu (3 madde) eşler arası sadakate verilen önemin artması şeklinde yorumlanmaktadır. Şiddet (ŞiD) alt boyutundan ( 2 madde) yüksek puan alınması "aile saadeti" için şiddeti meşru görme olarak yorumlanmaktadır. Yüksek puan her alt boyut için olumlu olarak puanlanmaktadır. Ölçek iç tutarlık analizleri sonucunda ölçek toplam Cronbach Alpha güvenirlik katsayısı 0,89 olarak belirlenmiştir. Bu çalışmada ise ölçek toplam Cronbach Alpha güvenirlik katsayısı .78 bulunmuştur.

\section{Verilerin Toplanması ve Analizi}

Çalışma için Karabük Üniversitesi Sosyal ve Beşeri Bilimler Araştırmaları Etik Kurulu izni alınmıştır (07.02.2020 tarih ve 2020/2-19 no'lu karar). Veriler toplanırken kırsaldaki kadınlara ölçek maddeleri okunup verdikleri cevaplar işaretlenmiş veya yazılı olarak verilen ölçek formunu doldurmaları istenmiştir. Şehir merkezindeki kadınlarla çevrimiçi olarak iletişime geçilmiş, kendilerinden ölçek maddelerini çevrimiçi ortamda doldurmaları istenmiştir. Verilerin normallik dağılımı Kolmogorov Smirnov Testi ile incelenmiş ve değişkenlere göre normal dağılım olmadığı görülmüş, buna göre verilerin analizinde non-parametrik testlerden yararlanılmıştır. İkili değişkenlerde Mann Whitney U (MWU) testi, üç ve üzeri değişkenlerde Kruskal Wallis $\mathrm{H}(\mathrm{KWH})$ testi uygulanmıştır. Anlamlılık değeri 0,05 olarak alınmıştır.

\section{Bulgular}

Bu bölümde, çalışma grubunun ikamet yeri, çalışma durumu, yaşı, öğrenim durumu, evlilik süresi ve çocuk sayısı değişkenlerine göre elde edilen bulgular verilmiştir. Tablo 2'de kırsal ve kentte ikamet etme durumuna göre, Tablo 3'te bir işte çalışıp çalışmama durumuna, Tablo 4'te yaşa, Tablo 5 'te öğrenim durumuna, Tablo 6'da evlilik süresine ve Tablo 7'de çocuk sayısı değişkenlerine göre Aile Değerleri Ölçeği analiz sonuçları sunulmuştur. 


\begin{tabular}{|c|c|c|c|c|c|c|}
\hline Aile Değerleri Ölçeği & İkamet & $\mathrm{n}$ & $\overline{\mathrm{X}}$ & $\mathrm{S}$ & $\mathrm{z}$ & $\mathrm{p}$ \\
\hline \multirow{2}{*}{ Geleneksel Aile Değerleri } & Kirsal & 60 & 19,13 & 2,94 & $-9,577$ & $0,000 *$ \\
\hline & Kent & 84 & 9,63 & 3,19 & & \\
\hline \multirow{2}{*}{ Cinselliğe Bakış } & Kirsal & 60 & 9,55 & 2,89 & $-10,221$ & $0,000 *$ \\
\hline & Kent & 84 & 19,67 & 1,80 & & \\
\hline \multirow{2}{*}{ Anne-Çocuk İlişkisi } & Kırsal & 60 & 18,43 & 2,66 & $-7,781$ & $0,000 *$ \\
\hline & Kent & 84 & 14,71 & 2,30 & & \\
\hline \multirow{2}{*}{ Çocuğun Değeri } & Kirsal & 60 & 18,26 & 2,25 & $-9,666$ & $0,000 *$ \\
\hline & Kent & 84 & 11,48 & 2,69 & & \\
\hline \multirow{2}{*}{ Karar Alma Süreçleri } & Kirsal & 60 & 16,95 & 2,54 & $-8,480$ & $0,000 *$ \\
\hline & Kent & 84 & 12,27 & 2,29 & & \\
\hline \multirow[b]{2}{*}{ Evliliğe Bakış } & Kirsal & 60 & 17,66 & 2,39 &,- 210 & 0,833 \\
\hline & Kent & 84 & 17,80 & 2,69 & & \\
\hline \multirow{2}{*}{ Kadının Rolleri } & Kirsal & 60 & 15,38 & 2,80 &,- 263 & 0,793 \\
\hline & Kent & 84 & 15,45 & 3,03 & & \\
\hline \multirow{2}{*}{ Farklı Yaklaşımlar } & Kirsal & 60 & 12,51 & 3,21 & $-9,002$ & $0,000 *$ \\
\hline & Kent & 84 & 19,01 & 2,42 & & \\
\hline \multirow{2}{*}{ Sosyo-Ekonomik Değer } & Kirsal & 60 & 14,71 & 2,85 & $-1,974$ & $0,048 *$ \\
\hline & Kent & 84 & 13,59 & 2,98 & & \\
\hline \multirow{2}{*}{ Akraba İlişkileri } & Kirsal & 60 & 18,83 & 2,17 & $-7,651$ & $0,000 *$ \\
\hline & Kent & 84 & 15,29 & 2,12 & & \\
\hline \multirow{2}{*}{ Duygusal Bağ } & Kirsal & 60 & 16,03 & 5,56 & $-7,306$ & $0,000 *$ \\
\hline & Kent & 84 & 12,60 & 1,79 & & \\
\hline \multirow{2}{*}{ Sadakat } & Kirsal & 60 & 10,85 & 2,07 & $-3,421$ & $0,001 *$ \\
\hline & Kent & 84 & 12,02 & 2,08 & & \\
\hline \multirow{2}{*}{ Şiddet } & Kirsal & 60 & 4,28 & 2,13 & $-9,747$ & $0,000 *$ \\
\hline & Kent & 84 & 9,32 & 1,20 & & \\
\hline
\end{tabular}

$* \mathrm{p}<0,05$

Tablo 2'ye göre kadınların ikamet ettikleri yer ile Aile Değerleri Ölçeği Geleneksel Aile Değerleri, Cinselliğe Bakış, Anne-Çocuk İlişkisi, Çocuğun Değeri, Karar Alma Süreçleri, Farklı Yaklaşımlar, Sosyo-Ekonomik Değer, Akraba İlişkileri, Duygusal Bağ, Sadakat ve Şiddet alt boyutları puan ortalamaları arasında anlamlı farklılık vardır $(\mathrm{p}<0,05)$. Kırsalda ikamet edenlerin Geleneksel Aile Değerleri, Anne-Çocuk İlişkisi, Çocuğun Değeri, Karar Alma Süreçleri, Sosyo-Ekonomik Değer, Akraba İlişkileri ve Duygusal Bağ alt boyutları puan ortalama$\operatorname{lar} 1(\overline{\mathrm{x}}: 19,13, \overline{\mathrm{x}}: 18,43, \overline{\mathrm{x}}: 18,26 \overline{\mathrm{x}}: 16,95, \overline{\mathrm{x}}: 14,71, \overline{\mathrm{x}}: 18,83, \overline{\mathrm{x}}: 16,03)$ kentte ikamet edenlerin puanlarından $(\overline{\mathrm{x}}: 9,63, \overline{\mathrm{x}}: 14,71, \overline{\mathrm{x}}: 11,48 \mathrm{x}: 12,27, \overline{\mathrm{x}}: 13,59, \overline{\mathrm{x}}: 15,29$, $\overline{\mathrm{x}}: 12,60)$ daha yüksekken; Cinselliğe Bakış, Farklı Yaklaşımlar, Sadakat ve Şid- 
det puan ortalamaları $(\overline{\mathrm{x}}: 9,55, \overline{\mathrm{x}}: 12,51, \overline{\mathrm{x}}: 10,85, \overline{\mathrm{x}}: 4,28)$ kentte yaşayanların puanlarından ( $\mathrm{x}: 19,67, \bar{x}: 19,01, \bar{x}: 12,02, \bar{x}: 9,32)$ daha düşük bulunmuştur.

\begin{tabular}{|c|c|c|c|c|c|c|}
\hline Aile Değerleri Ölçeği & $\begin{array}{l}\text { Çalışma } \\
\text { Durumu }\end{array}$ & $\mathrm{n}$ & $\overline{\mathrm{x}}$ & $\mathrm{S}$ & $\mathrm{z}$ & $\mathrm{p}$ \\
\hline \multirow{2}{*}{ Geleneksel Aile Değerleri } & Çalışmıyor & 101 & 15,23 & 5,60 & $-5,246$ & $0,000 *$ \\
\hline & Çalışıyor & 43 & 9,72 & 3,32 & & \\
\hline \multirow{2}{*}{ Cinselliğe Bakış } & Çalışmıyor & 101 & 13,90 & 5,82 & $-4,104$ & $0,000 *$ \\
\hline & Çalışıyor & 43 & 19,11 & 1,80 & & \\
\hline \multirow{2}{*}{ Anne-Çocuk İlişkisi } & Çalışmiyor & 101 & 16,94 & 3,06 & $-4,303$ & $0,000 *$ \\
\hline & Çalışıyor & 43 & 14,67 & 2,41 & & \\
\hline \multirow{2}{*}{ Çocuğun Değeri } & Çalışmıyor & 101 & 15,39 & 4,28 & $-4,914$ & $0,000 *$ \\
\hline & Çalışıyor & 43 & 11,76 & 2,58 & & \\
\hline \multirow{2}{*}{ Karar Alma Süreçleri } & Çalışmiyor & 101 & 15,03 & 3,37 & $-4,423$ & $0,000 *$ \\
\hline & Çalışıyor & 43 & 12,30 & 2,29 & & \\
\hline \multirow{2}{*}{ Evliliğe Bakış } & Çalışmıyor & 101 & 17,44 & 2,40 & $-2,326$ & $0,020 *$ \\
\hline & Çalışıyor & 43 & 18,46 & 2,83 & & \\
\hline \multirow{2}{*}{ Kadının Rolleri } & Çalışmiyor & 101 & 15,12 & 2,62 & $-1,986$ & $0,047 *$ \\
\hline & Çalışıyor & 43 & 16,11 & 3,47 & & \\
\hline \multirow{2}{*}{ Farklı Yaklaşımlar } & Çalışmıyor & 101 & 15,08 & 4,19 & $-5,212$ & $0,000^{*}$ \\
\hline & Çalışıyor & 43 & 19,16 & 2,72 & & \\
\hline \multirow{2}{*}{ Sosyo-Ekonomik Değer } & Çalışmiyor & 101 & 14,27 & 2,81 & $-1,030$ & 0,303 \\
\hline & Çalışıyor & 43 & 13,55 & 3,30 & & \\
\hline \multirow{2}{*}{ Akraba İlişkileri } & Çalışmıyor & 101 & 17,53 & 2,61 & $-5,094$ & $0,000 *$ \\
\hline & Çalışıyor & 43 & 14,97 & 2,25 & & \\
\hline \multirow{2}{*}{ Duygusal Bağ } & Çalışmıyor & 101 & 14,68 & 4,74 & $-4,427$ & $0,000 *$ \\
\hline & Çalışıyor & 43 & 12,51 & 1,66 & & \\
\hline \multirow{2}{*}{ Sadakat } & Çalışmıyor & 101 & 11,33 & 2,16 & $-1,512$ & 0,130 \\
\hline & Çalışıyor & 43 & 12,00 & 2,07 & & \\
\hline \multirow{2}{*}{ Şiddet } & Çalışmıyor & 101 & 6,26 & 3,03 & $-6,028$ & $0,000 *$ \\
\hline & Çalışıyor & 43 & 9,46 & 1,07 & & \\
\hline
\end{tabular}

$* \mathrm{p}<0,05$

Tablo 3'e göre kadınların çalışma durumu ile Aile Değerleri Ölçeği Geleneksel Aile Değerleri, Cinselliğe Bakış, Anne-Çocuk İlişkisi, Çocuğun Değeri, Karar Alma Süreçleri, Evliliğe Bakış, Kadının Rolleri, Farklı Yaklaşımlar, Akraba İlişkileri, Duygusal Bağ ve Şiddet alt boyutları puan ortalamaları arasında anlamlı farklılık vardır $(\mathrm{p}<0,05)$. Çalışmayan kadınların Geleneksel Aile Değerleri, Anne-Çocuk İlişkisi, Karar Alma Süreçleri, Akraba İlişkileri ve Duygusal Bağ alt boyutları puan ortalamaları ( $\overline{\mathrm{x}}: 15,23, \overline{\mathrm{x}}: 16,94, \overline{\mathrm{x}}: 15,39, \overline{\mathrm{x}}: 15,03, \overline{\mathrm{x}}: 15,53, \overline{\mathrm{x}}: 14,68)$ 
çalışanların puanlarından $(\overline{\mathrm{x}}: 9,72, \overline{\mathrm{x}}: 14,67, \overline{\mathrm{x}}: 11,76, \overline{\mathrm{x}}: 12,30, \overline{\mathrm{x}}: 13,55, \overline{\mathrm{x}}: 12,51)$ daha yüksekken; Cinselliğe Bakış, Evliliğe Bakış, Kadının Rolleri, Farklı Yaklaşımlar ve Şiddet puan ortalamaları ( $\mathrm{x}: 13,90, \overline{\mathrm{x}}: 17,44, \overline{\mathrm{x}}: 15,12, \overline{\mathrm{x}}: 15,08, \overline{\mathrm{x}}: 6,26)$ çalışmayanların puanlarından ( $\overline{\mathrm{x}}: 19,11, \overline{\mathrm{x}}: 18,46, \overline{\mathrm{x}}: 16,11, \overline{\mathrm{x}}: 19,16, \overline{\mathrm{x}}: 9,46)$ daha düşük bulunmuştur.

\begin{tabular}{|c|c|c|c|c|c|c|}
\hline Aile Değerleri Ölçeği & Yaş & $\mathrm{n}$ & $\overline{\mathrm{X}}$ & $\mathrm{S}$ & $\mathrm{H}$ & $\mathrm{p}$ \\
\hline \multirow{3}{*}{ Geleneksel Aile Değerleri } & 30 yaş ve altı & 92 & 10,48 & 4,22 & 71,623 & $0,000 *$ \\
\hline & $31-40$ yaş & 36 & 18,66 & 3,23 & \multirow{2}{*}{ Fark: $1-2,3$} & \\
\hline & $41-50$ yaş & 16 & 20,00 & 2,00 & & \\
\hline \multirow{3}{*}{ Cinselliğe Bakış } & 30 yaş ve altı & 92 & 18,61 & 3,90 & 75,516 & $0,000 *$ \\
\hline & $31-40$ yaş & 36 & 10,36 & 2,75 & \multirow{2}{*}{ Fark: $1-2,3$} & \\
\hline & $41-50$ yaş & 16 & 8,75 & 2,90 & & \\
\hline \multirow{3}{*}{ Anne-Çocuk İlişkisi } & 30 yaş ve altı & 92 & 15,18 & 2,77 & 42,169 & $0,000 *$ \\
\hline & $31-40$ yaş & 36 & 17,77 & 2,69 & \multirow{2}{*}{ Fark: $1-2,3$} & \\
\hline & $41-50$ yaş & 16 & 19,06 & 2,17 & & \\
\hline \multirow{3}{*}{ Çocuğun Değeri } & 30 yaş ve altı & 92 & 12,17 & 3,51 & 69,680 & $0,000 *$ \\
\hline & $31-40$ yaş & 36 & 17,97 & 2,10 & \multirow{2}{*}{ Fark: $1-2,3$} & \\
\hline & 41-50 yaş & 16 & 18,37 & 2,09 & & \\
\hline \multirow{3}{*}{ Karar Alma Süreçleri } & 30 yaş ve altı & 92 & 12,81 & 2,86 & 48,580 & $0,000 *$ \\
\hline & $31-40$ yaş & 36 & 16,77 & 2,25 & \multirow{2}{*}{ Fark: $1-2,3$} & \\
\hline & $41-50$ yaş & 16 & 16,56 & 3,20 & & \\
\hline \multirow{3}{*}{ Evliliğe Bakış } & 30 yaş ve altı & 92 & 17,81 & 2,62 & 0,563 & 0,755 \\
\hline & $31-40$ yaş & 36 & 17,41 & 2,69 & & \\
\hline & 41-50 yaş & 16 & 18,12 & 1,92 & & \\
\hline \multirow{3}{*}{ Kadının Rolleri } & 30 yaş ve altı & 92 & 15,36 & 3,00 & 0,107 & 0,948 \\
\hline & $31-40$ yaş & 36 & 15,50 & 2,70 & & \\
\hline & 41-50 yaş & 16 & 15,56 & 3,16 & & \\
\hline \multirow{3}{*}{ Farklı Yaklaşımlar } & 30 yaş ve altı & 92 & 18,31 & 3,41 & 60,550 & $0,000 *$ \\
\hline & $31-40$ yaş & 36 & 12,88 & 3,44 & \multirow{2}{*}{ Fark: $1-2,3$} & \\
\hline & 41-50 yaş & 16 & 12,43 & 2,06 & & \\
\hline \multirow{3}{*}{ Sosyo-Ekonomik Değer } & 30 yaş ve altı & 92 & 13,54 & 2,94 & 8,372 & $0,015^{*}$ \\
\hline & $31-40$ yaş & 36 & 14,63 & 2,46 & \multirow{2}{*}{ Fark: $1-2,3$} & \\
\hline & $41-50$ yaş & 16 & 15,75 & 3,49 & & \\
\hline \multirow{3}{*}{ Akraba İlişkileri } & 30 yaş ve altı & 92 & 15,68 & 2,43 & 42,319 & $0,000 *$ \\
\hline & $31-40$ yaş & 36 & 18,25 & 2,08 & \multirow{2}{*}{ Fark: 1-2, 3} & \\
\hline & 41-50 yaş & 16 & 19,68 & 2,30 & & \\
\hline
\end{tabular}




\begin{tabular}{|c|c|c|c|c|c|c|}
\hline \multirow{3}{*}{ Duygusal Bağ } & 30 yaş ve altı & 92 & 12,85 & 1,94 & 41,269 & $0,000 *$ \\
\hline & $31-40$ yaş & 36 & 16,19 & 7,08 & \multirow{2}{*}{\multicolumn{2}{|c|}{ Fark: 1-2, 3}} \\
\hline & $41-50$ yaş & 16 & 15,93 & 1,91 & & \\
\hline \multirow{3}{*}{ Sadakat } & 30 yaş ve altı & 92 & 12,00 & 2,05 & 12,126 & $0,002 *$ \\
\hline & $31-40$ yaş & 36 & 10,66 & 2,13 & \multirow{2}{*}{\multicolumn{2}{|c|}{ Fark: 1-2, 3}} \\
\hline & $41-50$ yaş & 16 & 10,81 & 2,07 & & \\
\hline \multirow{3}{*}{ Şiddet } & 30 yaş ve altı & 92 & 8,81 & 2,05 & 71,502 & $0,000 *$ \\
\hline & $31-40$ yaş & 36 & 4,08 & 1,99 & \multirow{2}{*}{\multicolumn{2}{|c|}{ Fark: 1-2, 3}} \\
\hline & 41-50 yaş & 16 & 5,12 & 2,52 & & \\
\hline
\end{tabular}

*p $<0,05$

Tablo 4'e göre kadınların yaşı ile Aile Değerleri Ölçeği Geleneksel Aile Değerleri, Cinselliğe Bakış, Anne-Çocuk İlişkisi, Çocuğun Değeri, Karar Alma Süreçleri, Farklı Yaklaşımlar, Sosyo-Ekonomik Değer, Akraba İlişkileri, Duygusal Bağ, Sadakat ve Şiddet alt boyutları puan ortalamaları arasında anlamlı farklılık vardır $(p<0,05)$. Farkın kaynağ incelendiğinde, 30 yaş ve daha küçük yaştakilerin Geleneksel Aile Değerleri, Anne-Çocuk İlişkisi, Çocuğun Değeri, Karar Alma Süreçleri, Sosyo-Ekonomik Değer, Akraba İlişkileri ve Duygusal Bağ alt boyut puan ortalamaları ( $\mathrm{x}: 10,48, \overline{\mathrm{x}}: 15,18, \overline{\mathrm{x}}: 12,17, \overline{\mathrm{x}}: 12,81, \overline{\mathrm{x}}: 13,54$, $\overline{\mathrm{x}}: 15,68, \overline{\mathrm{x}}: 12,85)$ 31-40 yaş ve 41-50 yaş aralığındakilerin puanlarından anlamlı ölçüde düşükken; Cinselliğe Bakış, Farklı Yaklaşımlar, Sadakat ve Şiddet puan ortalamaları ( $\overline{\mathrm{x}}: 18,61, \overline{\mathrm{x}}: 18,31, \overline{\mathrm{x}}: 12,00, \overline{\mathrm{x}}: 8,81) 31-40$ yaş ve $41-50$ yaşındakilerin puanlarından daha yüksek bulunmuştur.

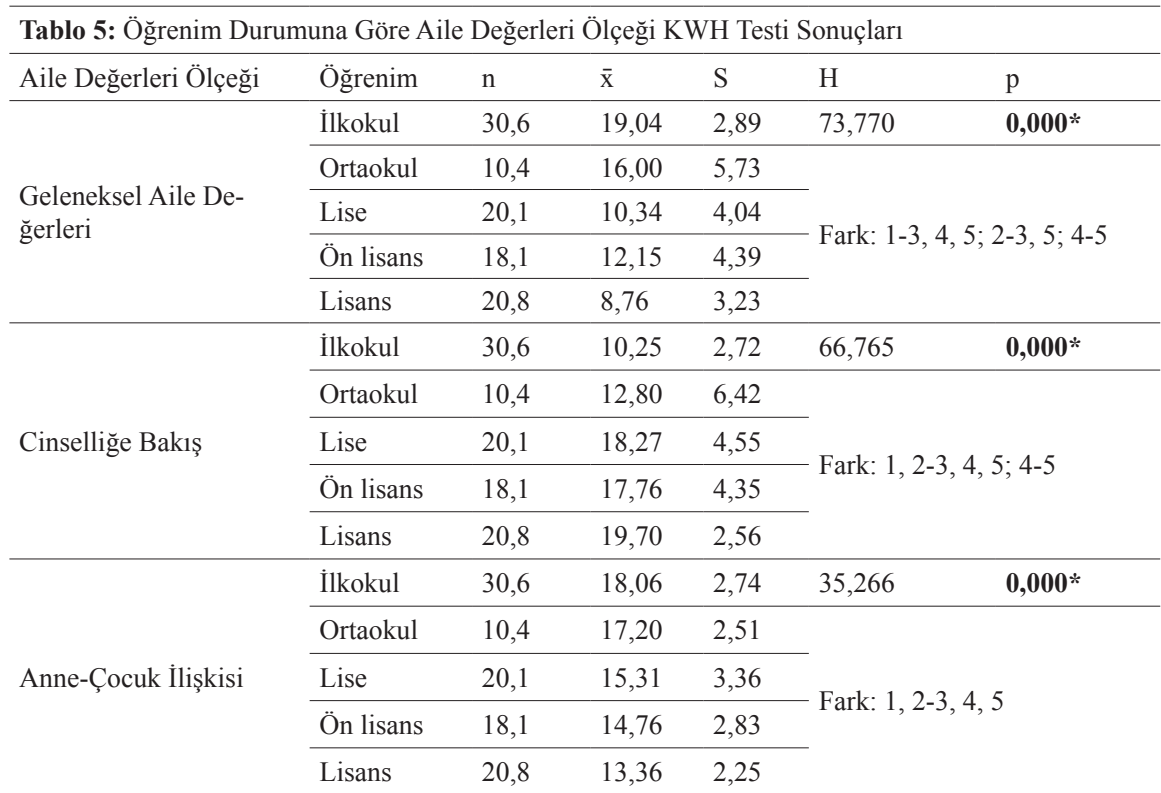




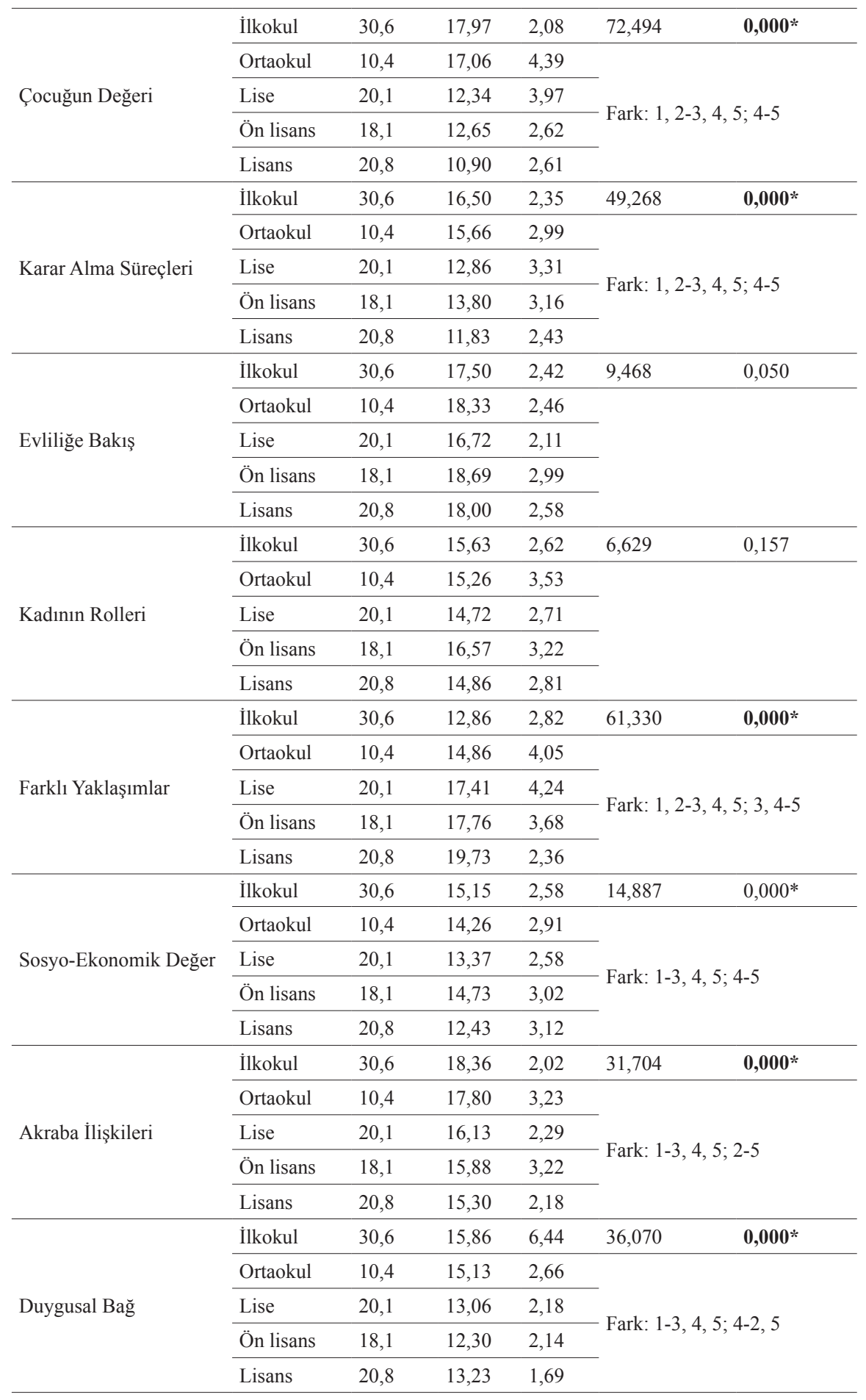




\begin{tabular}{|c|c|c|c|c|c|c|}
\hline \multirow{5}{*}{ Sadakat } & İlkokul & 30,6 & 10,61 & 1,93 & 16,664 & $0,000 *$ \\
\hline & Ortaokul & 10,4 & 10,80 & 2,27 & \multirow{4}{*}{\multicolumn{2}{|c|}{ Fark: $1-3,4,5 ; 2-3,4$}} \\
\hline & Lise & 20,1 & 12,10 & 1,73 & & \\
\hline & Ön lisans & 18,1 & 12,15 & 2,39 & & \\
\hline & Lisans & 20,8 & 12,16 & 2,08 & & \\
\hline \multirow{5}{*}{ Şiddet } & İlkokul & 30,6 & 4,65 & 2,23 & 67,072 & $0,000 *$ \\
\hline & Ortaokul & 10,4 & 5,13 & 3,02 & \multirow{4}{*}{\multicolumn{2}{|c|}{ Fark: $1-2,3 ; 2-3,4,5$}} \\
\hline & Lise & 20,1 & 8,82 & 1,90 & & \\
\hline & Ön lisans & 18,1 & 8.69 & 2,42 & & \\
\hline & Lisans & 20,8 & 9,20 & 1,71 & & \\
\hline
\end{tabular}

*p $<0,05$

Tablo 5'e göre kadınların öğrenim durumu ile Aile Değerleri Ölçeği Geleneksel Aile Değerleri, Cinselliğe Bakış, Anne-Çocuk İlişkisi, Çocuğun Değeri, Karar Alma Süreçleri, Farklı Yaklaşımlar, Sosyo-Ekonomik Değer, Akraba İlişkileri, Duygusal Bağ, Sadakat ve Şiddet alt boyutları puan ortalamaları arasında anlamlı farklılık vardır $(\mathrm{p}<0,05)$. Farkın kaynağı incelendiğinde, ilkokul mezunlarının Geleneksel Aile Değerleri alt boyut puan ortalamaları ( $\overline{\mathrm{x}}: 19,04)$ lise, ön lisans ve lisans mezunlarının puanlarından ( $\overline{\mathrm{x}}: 10,34, \overline{\mathrm{x}}: 12,15, \overline{\mathrm{x}}: 8,76)$; ortaokul mezunlarının puan ortalamaları $(\overline{\mathrm{x}}: 16,00)$ lise ve lisans mezunlarının puanlarından, ön lisans mezunlarının puan ortalamaları ise lisans mezunlarının puanlarından daha yüksek bulunmuştur. İlk ve ortaokul mezunlarının Cinselliğe Bakış alt boyutu puan ortalamaları ( $\overline{\mathrm{x}}: 10,25, \overline{\mathrm{x}}: 12,80)$ lise, ön lisans ve lisans mezunlarının puanlarından ( $\overline{\mathrm{x}}: 18,27, \overline{\mathrm{x}}: 17,76, \overline{\mathrm{x}}: 19,70)$, ön lisans mezunlarının puan ortalamaları ise lisans mezunlarının puanlarından düşük bulunmuştur. İlk ve ortaokul mezunlarının Anne-Çocuk İlişkisi puan ortalamaları ( $\bar{x}: 18,06$, $\overline{\mathrm{x}}: 17,20)$ lise, ön lisans ve lisans mezunlarının puanlarından ( $\mathrm{x}: 15,31, \overline{\mathrm{x}}: 14,76$, $\overline{\mathrm{x}}: 13,36)$ yüksek bulunmuştur. İlk ve ortaokul mezunlarının Çocuğun Değeri alt boyutu puan ortalamaları ( $\overline{\mathrm{x}}: 17,97, \overline{\mathrm{x}}: 17,06)$ lise, ön lisans ve lisans mezunlar1nın puanlarından ( $\overline{\mathrm{x}}: 12,34, \overline{\mathrm{x}}: 12,65, \overline{\mathrm{x}}: 10,90)$, ön lisans mezunlarının puan ortalamaları ise lisans mezunlarının puanlarından yüksek bulunmuştur. İlk ve ortaokul mezunlarının Karar Alma Süreçleri puan ortalamaları ( $\mathrm{x}: 16,50, \overline{\mathrm{x}}: 15,66)$ lise, ön lisans ve lisans mezunlarının puanlarından ( $\mathrm{x}: 12,86, \overline{\mathrm{x}}: 13,80, \overline{\mathrm{x}}: 11,83)$, ön lisans mezunlarının puan ortalamaları ise lisans mezunlarının puanlarından yüksek bulunmuştur. İlk ve ortaokul mezunlarının Farklı Yaklaşımlar alt boyutu puan ortalamaları ( $\overline{\mathrm{x}}: 12,86, \overline{\mathrm{x}}: 14,86)$ lise, ön lisans ve lisans mezunlarının puanlarından ( $\overline{\mathrm{x}}: 17,41, \overline{\mathrm{x}}: 17,76, \overline{\mathrm{x}}: 19,73)$, lise ve ön lisans mezunlarının puanları ise lisans mezunlarının puanından daha düşük bulunmuştur. İlkokul mezunlarının Sosyo-Ekonomik Değer alt boyutu puan ortalamaları $(\overline{\mathrm{x}}: 16,15)$ lise, ön lisans ve 
lisans mezunlarının puanlarından ( $\overline{\mathrm{x}}: 13,37, \overline{\mathrm{x}}: 14,73, \overline{\mathrm{x}}: 12,43)$, ön lisans mezunlarının puanı ise lisans mezunlarının puanından yüksek bulunmuştur. İlkokul mezunlarının Akraba İlişkileri alt boyutu puan ortalamaları ( $\overline{\mathrm{x}}: 18,36)$ lise, ön lisans ve lisans mezunlarının puanlarından ( $\overline{\mathrm{x}}: 16,13, \overline{\mathrm{x}}: 15,88, \overline{\mathrm{x}}: 15,30)$, ortaokul mezunlarının puan ortalamaları $(\overline{\mathrm{x}}: 17,80)$ lisans mezunlarının puanından daha yüksek bulunmuştur. İlkokul mezunlarının Duygusal Bağ alt boyutu puan ortalamaları $(\overline{\mathrm{x}}: 15,86)$ lise, ön lisans ve lisans mezunlarının puan ortalamalarından $(\overline{\mathrm{x}}: 13,06, \overline{\mathrm{x}}: 12,30, \overline{\mathrm{x}}: 13,23)$, ön lisans mezunlarının puan ortalamaları ise ortaokul ve lisans mezunlarının puan ortalamalarından $(\overline{\mathrm{x}}: 15,13, \overline{\mathrm{x}}: 13,23)$ daha düşük bulunmuştur. İlkokul mezunlarının Sadakat alt boyutu puan ortalamaları $(\overline{\mathrm{x}}: 10,61)$ lise, ön lisans ve lisans mezunlarının puan ortalamalarından $(\overline{\mathrm{x}}: 12,30$, $\overline{\mathrm{x}}: 12,15, \overline{\mathrm{x}}: 12,16)$, ortaokul mezunlarının puan ortalamaları $(\overline{\mathrm{x}}: 10,80)$ ise lise ve ön lisans mezunlarının puanlarından daha düşük bulunmuştur. İlkokul mezunlarının Şiddet alt boyutu puan ortalamaları $(\overline{\mathrm{x}}: 4,65)$ ortaokul ve lise mezunlarının puan ortalamalarından $(\overline{\mathrm{x}}: 5,13, \overline{\mathrm{x}}: 8,82)$, ortaokul mezunlarının puan ortalamaları ise $(\overline{\mathrm{x}}: 5,13)$ lise, ön lisans ve lisans mezunlarının puanlarından $(\overline{\mathrm{x}}: 8,82$, $\overline{\mathrm{x}}: 8,69, \overline{\mathrm{x}}: 9,20)$ daha düşük bulunmuştur.

\begin{tabular}{|c|c|c|c|c|c|c|}
\hline Aile Değerleri Ölçeği & Evlilik Süresi & $\mathrm{n}$ & $\overline{\mathrm{x}}$ & $\mathrm{S}$ & $\mathrm{H}$ & $\mathrm{p}$ \\
\hline \multirow{3}{*}{$\begin{array}{l}\text { Geleneksel Aile De- } \\
\text { ğerleri }\end{array}$} & $1-10$ y1l & 95 & 10,75 & 4,44 & 65,862 & $0,000 *$ \\
\hline & $11-20 \mathrm{y} 1 \mathrm{l}$ & 37 & 18,70 & 3,12 & \multirow[t]{2}{*}{ Fark: 1-2, 3} & \\
\hline & 21 yıl ve üzeri & 12 & 20,25 & 2,17 & & \\
\hline \multirow{3}{*}{ Cinselliğe Bakış } & $1-10 \mathrm{y} 11$ & 95 & 18,34 & 4,15 & 69,209 & $0,000 *$ \\
\hline & $11-20$ y1l & 37 & 10,16 & 2,86 & \multirow[t]{2}{*}{ Fark: $1-2,3$} & \\
\hline & 21 yıl ve üzeri & 12 & 8,91 & 2,90 & & \\
\hline \multirow{3}{*}{ Anne-Çocuk İlişsisi } & $1-10$ y1l & 95 & 15,26 & 2,76 & 40,475 & $0,000 *$ \\
\hline & $11-20$ y1l & 37 & 17,81 & 2,84 & \multirow[t]{2}{*}{ Fark: $1-2,3$} & \\
\hline & 21 yıl ve üzeri & 12 & 19,41 & 1,62 & & \\
\hline \multirow{3}{*}{ Çocuğun Değeri } & $1-10$ y1l & 95 & 12,34 & 3,58 & 63,653 & $0,000 *$ \\
\hline & $11-20 \mathrm{y} 11$ & 37 & 18,24 & 2,19 & \multirow[t]{2}{*}{ Fark: 1-2, 3} & \\
\hline & 21 yıl ve üzeri & 12 & 17,75 & 2,05 & & \\
\hline \multirow{3}{*}{ Karar Alma Süreçleri } & $1-10$ yil & 95 & 12,98 & 2,98 & 40,977 & $0,000 *$ \\
\hline & $11-20$ y1l & 37 & 16,64 & 2,50 & \multirow[t]{2}{*}{ Fark: 1-2, 3} & \\
\hline & 21 yıl ve üzeri & 12 & 16,50 & 2,93 & & \\
\hline \multirow{3}{*}{ Evliliğe Bakış } & $1-10$ y1l & 95 & 17,77 & 2,69 & 0,019 & 0,990 \\
\hline & $11-20$ y1l & 37 & 17,64 & 2,49 & & \\
\hline & 21 yıl ve üzeri & 12 & 17,83 & 1,89 & & \\
\hline
\end{tabular}




\begin{tabular}{|c|c|c|c|c|c|c|}
\hline \multirow{3}{*}{ Kadının Rolleri } & $1-10$ y1l & 95 & 15,48 & 3,12 & 0,563 & 0,755 \\
\hline & $11-20 \mathrm{y} 11$ & 37 & 15,45 & 2,62 & & \\
\hline & 21 yıl ve üzeri & 12 & 14,83 & 2,24 & & \\
\hline \multirow{3}{*}{ Farklı Yaklaşımlar } & $1-10 \mathrm{y} 1 \mathrm{l}$ & 95 & 18,05 & 3,65 & 50,451 & $0,000 *$ \\
\hline & $11-20$ y1l & 37 & 13,08 & 3,36 & Fark: 1-2, 3 & \\
\hline & 21 yıl ve üzeri & 12 & 12,41 & 2,19 & & \\
\hline \multirow{3}{*}{$\begin{array}{l}\text { Sosyo-Ekonomik } \\
\text { Değer }\end{array}$} & $1-10 \mathrm{y} 11$ & 95 & 13,65 & 3,05 & 5,743 & 0,057 \\
\hline & $11-20 \mathrm{y} 1 \mathrm{l}$ & 37 & 14,75 & 2,44 & & \\
\hline & 21 yıl ve üzeri & 12 & 15,16 & 3,37 & & \\
\hline \multirow{3}{*}{ Akraba İlişkileri } & $1-10 \mathrm{y} 11$ & 95 & 15,70 & 2,36 & 44,320 & $0,000 *$ \\
\hline & $11-20 \mathrm{y} 11$ & 37 & 18,37 & 2,22 & Fark: 1-2, 3 & \\
\hline & 21 yıl ve üzeri & 12 & 20,25 & 1,95 & & \\
\hline \multirow{3}{*}{ Duygusal Bağ } & $1-10 \mathrm{y} 11$ & 95 & 12,95 & 1,98 & 35,375 & $0,000 *$ \\
\hline & $11-20 \mathrm{y} 11$ & 37 & 16,13 & 7,01 & Fark: 1-2, 3 & \\
\hline & 21 yıl ve üzeri & 12 & 16,08 & 1,92 & & \\
\hline \multirow{3}{*}{ Sadakat } & $1-10$ yil & 95 & 11,94 & 2,08 & 9,958 & $0,007 *$ \\
\hline & $11-20 \mathrm{y} 11$ & 37 & 10,70 & 2,05 & Fark: 1-2 & \\
\hline & 21 yıl ve üzeri & 12 & 10,83 & 2,24 & & \\
\hline \multirow{3}{*}{ Şiddet } & $1-10 \mathrm{y} 1 \mathrm{l}$ & 95 & 8,70 & 2.22 & 67,777 & $0,000 *$ \\
\hline & $11-20 \mathrm{y} 11$ & 37 & 4,43 & 2,04 & Fark: 1-2, 3 & \\
\hline & 21 yıl ve üzeri & 12 & 4,08 & 2,06 & & \\
\hline
\end{tabular}

$* \mathrm{p}<0,05$

Tablo 6'ya göre kadınların evlilik süresi ile Aile Değerleri Ölçeği Geleneksel Aile Değerleri, Cinselliğe Bakış, Anne-Çocuk İlişkisi, Çocuğun Değeri, Karar Alma Süreçleri, Farklı Yaklaşımlar, Akraba İlişkileri, Duygusal Bağ, Sadakat ve Şiddet alt boyutları puan ortalamaları arasında anlamlı farklılık vardır $(p<0,05)$. Farkın kaynağı incelendiğinde, evlilik süreleri 1-10 yıl olanların Geleneksel Aile Değerleri, Anne-Çocuk İlişkisi, Çocuğun Değeri, Karar Alma Süreçleri, Akraba İlişkileri ve Duygusal Bağ alt boyut puan ortalamaları ( $\bar{x}: 10,75$, $\overline{\mathrm{x}}: 15,26, \overline{\mathrm{x}}: 12,34, \overline{\mathrm{x}}: 12,98, \overline{\mathrm{x}}: 15,70, \overline{\mathrm{x}}: 12,95)$ evlilik süreleri $11-20$ ve 12 y1l ve üzeri olanların puanlarından $(\overline{\mathrm{x}}: 18,70, \overline{\mathrm{x}}: 20,25, \overline{\mathrm{x}}: 17,81, \overline{\mathrm{x}}: 19,41, \overline{\mathrm{x}}: 18,24$, $\overline{\mathrm{x}}: 17,75, \overline{\mathrm{x}}: 16,64, \overline{\mathrm{x}}: 16,50, \overline{\mathrm{x}}: 18,37, \overline{\mathrm{x}}: 20,25, \overline{\mathrm{x}}: 16,13, \overline{\mathrm{x}}: 16,08)$ anlamlı ölçüde düşükken; Cinselliğe Bakış, Farklı Yaklaşımlar, Sadakat ve Şiddet puan ortalamaları ( $\overline{\mathrm{x}}: 18,34, \overline{\mathrm{x}}: 18,05, \overline{\mathrm{x}}: 8,70)$ evlilik süreleri $11-20$ ve 12 yıl ve üzeri olanların puanlarından ( $\overline{\mathrm{x}}: 10,16, \overline{\mathrm{x}}: 8,91, \overline{\mathrm{x}}: 13,08, \overline{\mathrm{x}}: 12,41, \overline{\mathrm{x}}: 4,43, \overline{\mathrm{x}}: 4,08)$, evlilik süreleri 1-10 yıl olanların ise sadakat puan ortalamaları $(\overline{\mathrm{x}}: 11,94)$ evlilik süreleri 11-20 yıl olanların puanlarından ( $\mathrm{x}: 10,70)$ daha yüksek bulunmuştur. 


\begin{tabular}{|c|c|c|c|c|c|c|}
\hline $\begin{array}{l}\text { Aile Değerleri } \\
\text { Ölçeği }\end{array}$ & Çocuk Sayısı & $\mathrm{n}$ & $\overline{\mathrm{x}}$ & $\mathrm{S}$ & $\mathrm{H}$ & $\mathrm{p}$ \\
\hline \multirow{4}{*}{$\begin{array}{l}\text { Geleneksel Aile } \\
\text { Değerleri }\end{array}$} & Yok & 7 & 10,71 & 4,23 & 9,799 & $0,020 *$ \\
\hline & Tek çocuk & 21 & 11,09 & 4,72 & \multirow{3}{*}{ Fark: 1, 3-4 } & \\
\hline & İki çocuk & 73 & 13,56 & 5,83 & & \\
\hline & Üç ve üzeri & 43 & 15,32 & 5,34 & & \\
\hline \multirow{4}{*}{ Cinselliğe Bakış } & Yok & 7 & 17,71 & 2,69 & 9,17 & $0,028 *$ \\
\hline & Tek çocuk & 21 & 18,52 & 4,51 & \multirow{3}{*}{ Fark: 2, 3-4 } & \\
\hline & İki çocuk & 73 & 15,45 & 5,41 & & \\
\hline & Üç ve üzeri & 43 & 13,60 & 5,79 & & \\
\hline \multirow{4}{*}{ Anne-Çocuk İlişskisi } & Yok & 7 & 15,85 & 2,11 & 6,908 & 0,075 \\
\hline & Tek çocuk & 21 & 15,00 & 3,03 & & \\
\hline & İki çocuk & 73 & 16,15 & 3,00 & & \\
\hline & Üç ve üzeri & 43 & 17,13 & 3,13 & & \\
\hline \multirow{4}{*}{ Çocuğun Değeri } & Yok & 7 & 11,42 & 3,15 & 14,680 & $0,002 *$ \\
\hline & Tek çocuk & 21 & 12,28 & 3,14 & \multirow{3}{*}{ Fark: 1, 3-4 } & \\
\hline & İki çocuk & 73 & 14,24 & 4,64 & & \\
\hline & Üç ve üzeri & 43 & 15,88 & 3,25 & & \\
\hline \multirow{4}{*}{$\begin{array}{l}\text { Karar Alma Sü- } \\
\text { reçleri }\end{array}$} & Yok & 7 & 12,42 & 1,13 & 7,104 & 0,069 \\
\hline & Tek çocuk & 21 & 13,57 & 2,90 & & \\
\hline & İki çocuk & 73 & 14,05 & 3,44 & & \\
\hline & Üç ve üzeri & 43 & 15,11 & 3,39 & & \\
\hline \multirow{4}{*}{ Evliliğe Bakış } & Yok & 7 & 18,57 & 3,59 & 5,571 & 0,134 \\
\hline & Tek çocuk & 21 & 18,57 & 2,76 & & \\
\hline & İki çocuk & 73 & 17,76 & 2,64 & & \\
\hline & Üç ve üzeri & 43 & 17,18 & 2,05 & & \\
\hline \multirow{4}{*}{ Kadının Rolleri } & Yok & 7 & 17,14 & 4,37 & 4,070 & 0,254 \\
\hline & Tek çocuk & 21 & 15,80 & 3,12 & & \\
\hline & İki çocuk & 73 & 15,43 & 2,74 & & \\
\hline & Üç ve üzeri & 43 & 14,93 & 2,84 & & \\
\hline \multirow{4}{*}{ Farklı Yaklaşımlar } & Yok & 7 & 18,71 & 2,36 & 13,010 & $0,005 *$ \\
\hline & Tek çocuk & 21 & 18,76 & 3,54 & \multirow{3}{*}{ Fark: $1,2-4 ; 2-3$} & \\
\hline & İki çocuk & 73 & 15,95 & 4,31 & & \\
\hline & Üç ve üzeri & 43 & 15,30 & 4,17 & & \\
\hline \multirow{4}{*}{$\begin{array}{l}\text { Sosyo-Ekonomik } \\
\text { Değer }\end{array}$} & Yok & 7 & 12,57 & 4,03 & 1,182 & 0,757 \\
\hline & Tek çocuk & 21 & 14,00 & 2,84 & & \\
\hline & İki çocuk & 73 & 14,10 & 3,09 & & \\
\hline & $\overline{\text { Üç ve üzeri }}$ & 43 & 14,25 & 2,66 & & \\
\hline
\end{tabular}




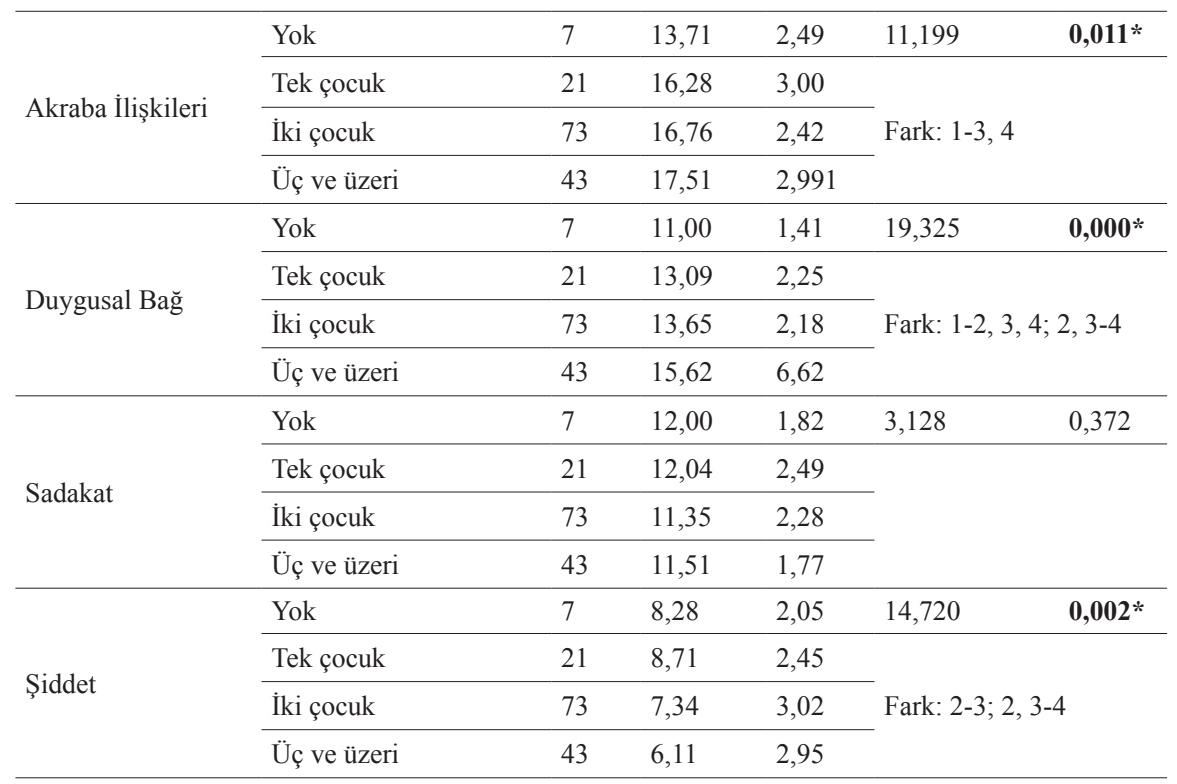

$* \mathrm{p}<0,05$

Tablo 7'ye göre göre kadınların çocuk sayısı değişkeni ile Aile Değerleri Ölçeği Geleneksel Aile Değerleri, Cinselliğe Bakış, Çocuğun Değeri, Farklı Yaklaşımlar, Akraba İlişkileri, Duygusal Bağ ve Şiddet alt boyutları puan ortalamaları arasında anlamlı farklılık vardır $(\mathrm{p}<0,05)$. Farkın kaynağı incelendiğinde, üç ve üzeri çocuğu olan kadınların Geleneksel Aile Değerleri, Çocuğun Değeri ve Akraba İlişkileri alt boyut puan ortalamaları ( $\overline{\mathrm{x}}: 15,32$, $\overline{\mathrm{x}}: 15,88, \overline{\mathrm{x}}: 17,51)$ çocuğu olmayan ve iki çocuğu olanların puanından ( $\overline{\mathrm{x}}: 10,71, \overline{\mathrm{x}}: 13,56, \overline{\mathrm{x}}: 11,42$, $\overline{\mathrm{x}}: 14,24, \bar{x}: 13,71, \bar{x}: 16,76)$ anlamlı düzeyde yüksektir. Üç ve üzeri çocuğu olanların Cinselliğe Bakış alt boyut puan ortalaması $(\bar{x}: 13,60)$ tek çocuk ve iki çocuğu olanların puanlarından ( $\mathrm{x}: 18,52, \bar{x}: 15,45)$ anlamlı düzeyde düşük bulunmuştur. Üç ve üzeri çocuğu olanların Farklı Yaklaşımlar puan ortalamaları $(\overline{\mathrm{x}}: 15,30)$ hiç çocuğu olmayan veya tek çocuğu olanların puanlarından ( $\mathrm{x}: 18,71, \bar{x}: 18,76)$ iki çocuğu olanların puan ortalamaları $(\overline{\mathrm{x}}: 15,95)$ ise tek çocuğu olanların puanlarından daha düşük bulunmuştur. Hiç çocuğu olmayanların Duygusal Bağ puan ortalaması $(\overline{\mathrm{x}}: 11,00)$ tek çocuk, iki ve üzeri çocuğu olanların puanlarından ( $\bar{x}: 13,09, \bar{x}: 13,65, \bar{x}: 15,62)$ düşükken; üç ve üzeri çocuğu olanların Duygusal Bağ puan ortalamaları tek çocuk ve iki çocuğu olanların puanlarından yüksek bulunmuştur. İki çocuğu olanların Şiddet alt boyut puan ortalamaları ( $\mathrm{x}: 7,34)$ tek çocuğu olanların puan ortalamalarından ( $\bar{x}: 8,71)$, üç ve üzeri çocuğu olanların da puan ortalamaları $(\overline{\mathrm{x}}: 6,11)$ tek çocuk ve iki çocuğa sahip kadınların puan ortalamalarından daha düşük bulunmuştur. 


\section{Tartışma, Sonuç ve Öneriler}

Kırsalda ve kentte ikamet eden kadınlarla yapılan bu çalışmada ikamet edilen yer, yaş, öğrenim durumu, çalışma durumu, evlilik süresi ve çocuk sayısı değişkenlerine göre kadınların aile değerleri incelenmiştir. Elde edilen bulgular ve alan yazın ışığında konu tartışılmış, çeşitli öneriler geliştirilmiştir.

Çalışmada kırsalda yaşayan kadınların kentte yaşayanlara göre daha fazla oranda aileyi geleneksel olarak değerlendirdikleri, çocuk bakımında anneye önem atfettikleri, çocuk yetiştirme rolüne önem verdikleri, ailede demokratik katılım olması gerektiğini düşündükleri, aileyi sosyal ve ekonomik bir yap1 olarak algıladıkları, akraba ilişkilerine önem verdikleri ve geniş aileye olumlu baktıkları belirlenmiştir. Kentte yaşayan kadınların kırsalda yaşayanlara göre daha fazla cinsellikle ilgili konularda serbestlikten yana oldukları, konvansiyonel olmayan değerleri önemsedikleri, eşler arası sadakate önem verdikleri ve aile saadeti için şiddeti meşru gördükleri belirlenmiş̧ir. Alan yazında bu sonuçla ilişkilendirilebilecek fazla çalışmaya rastlanmamakla birlikte Keskin (2016) kentleşme sürecinde ailenin değişimini konu aldığ çalışmasında ailede karar verme sürecinde, birlikte karar verme konusundaki görüşlerin köylerde kentten daha yüksek bir oranda olduğunu bulmuştur. Akraba ilişkileri göz önüne alındığında ise çocuklarının akrabalarından biriyle evlenmesine sıcak bakanların kırsalda kentin yaklaşık üç katı olduğu belirlenmiştir. Şahin (2019) çalışmasında bireyin nüfusa kayıtlı olduğu bölgeye göre aile değerleri alt boyutlarından duygusal bağ, sadakat, sosyoekonomik değer, şiddet alt boyut puanlarında anlamlı fark bulamazken anne çocuk ilişkisi, cinselliğe bakış, çocuğun değeri, evliliğe bakış, geleneksel aile değerleri, kadın rolleri, karar alma süreçleri, farklı yaklaşımlar alt boyut puanlarında anlamlı farklılık olduğunu bulmuştur. Ellena ve Nongkynrif (2017) yaptıkları çalışmada anasoylu toplumlarda cinsiyet rolleri daha esnek ve eşitlikçiyken babasoylu toplumlarda net bir şekilde hiyerarşik olduğunu, babasoylu toplumlarda kadınların sosyal statüsüne olumlu bakılmadığ bulunmuştur. Atkinson (1994) 199'u kırsal 763'ü kentli aileyle yaptığı çalışmasında çocuk bakımı konusunda kentli ailelerin daha çok bakıcıya başvurduğu kırsal kesimde yaşayan ailelerin ise çocuklarıyla ilgilenme konusunda daha çok akrabalardan yardım aldığı belirlenmiştir. Dewanggi, Hastuti ve Herawati (2015) çalışmalarında kırsal ve kentsel alandaki katılımcılar arasında anneye bağlılık açısından anlamlı bir fark olduğunu, kırsal bölgede yaşayan ailelerin anneye bağlanma puanlarının kentsel bölgelerde yaşayan ailelerden yüksek olduğu sonucuna varmışlardır. Scanzoni ve Arnett (1987) tarafından kırsal ve 
kette yaşayan eşlerin evlilik için çeşitli değişkenler üzerinden karşılaştırıldığ 1 çalışmada, en önemli farkın eğitim ve cinsiyet rolü tercihlerinde olduğu, kırsal kesimde yaşayan kadın ve erkeklerin kentte yaşayanlara göre daha az eğitimli ve toplumsal cinsiyet rolü tercihlerinin ise daha çok geleneksel olduğu belirtilmiştir. $\mathrm{Bu}$ çalışmalar araştırmamızın bulgusunu kısmen desteklerken Ekşi ve arkadaşları (2015) tarafından sosyo-ekonomik değer değişkeni ile aile değerleri alt boyutları arasında anlamlı bir farklılık bulunmadığının belirtildiği çalışma ile, Ajah ve arkadaşları (2014) tarafindan 376'sı kırsal 460'ı ise kentsel bir topluluktan olan 836 kadınla yapılan çalışmada kırsal kesimde yaşayan kadınların aile içi şiddeti kentte yaşayan kadınlara göre daha çok mazur gördüğü belirlenmiştir. Ayrıca aile içi şiddeti mazur görme nedenleri bakımından da çok farklı1ık olduğu, kırsal kesimde yaşayan kadınlar şiddetin eşlerine bildirmeden dışarı çıkan çocuklarını ihmal eden kadınlar için olabileceğini, kentsel kesimde yaşayan kadınlar ise eşleriyle cinsel ilişkide bulunmayı reddeden kadınlar için olabileceğini belirttikleri görülmüsstür. Özbay'ın (2014) kır ve kent yerleşim yeri karşılaştırmalarında kentlerde daha fazla akraba sahipliği olduğunu belirttiği çalışma ve Polat'ın (2020) katılımcıların büyüdüğü yer değişkenine göre anlamlı düzeyde bir farkın olmadığı sonucunu belirlendiği, üniversitede okuyan öğrencilerin kişilik özellikleri ve kendi aile değerleri arasındaki ilişkiyi incelediği çalışmalar araştırmanın bulgusuyla kısmen çelişmektedir. Araştırmanın sonucu düşünüldüğünde kırsal kesimde daha çok geleneksel aile yapısının varlığını devam ettirdiği, mahrem düşüncesinin yoğun olduğu cinsel konuların bu yüzden serbest konuşulamadığı, akrabalık bağlarının çok kuvvetli olduğu ve annenin çalışma hayatında olmamasından ötürü daha çok çocuk bakmakla yükümlü olduğu düşünülebilir.

Çalışmada çalışmayan/ev hanımı kadınların çalışan kadınlara göre daha fazla oranda aileyi geleneksel olarak değerlendirdikleri, çocuk bakımında anneye önem atfettikleri, çocuk yetiştirme rolüne önem verdikleri, ailede demokratik katılım olması gerektiğini düşündükleri, akraba ilişkilerine önem verdikleri ve geniş aileye olumlu baktıkları, aileye duygusal bağlılıklarının arttığı; çalışan kadınların ev hanımlarına göre daha fazla cinsellikle ilgili konularda serbestlikten yana oldukları, evlilik kurumuna önem verdikleri, kadını konvansiyonel bir bakış açısıyla değerlendirdikleri buna rağmen konvansiyonel olmayan değerlerin daha fazla benimsendiği ve aile saadeti için şiddeti meşru gördükleri belirlenmiştir. Acharya ve arkadaşları (2010) tarafından Nepal'de hane halkı içerisinde karar verme süreçlerinde kadınların özerkliğini konu alan çalışmada, çalışan kadınların çalışmayan kadınlara kıyasla karar alma sürecine katılma 
olasıllğının daha yüksek olduğu belirlenmiştir. Ekşi ve arkadaşları (2015) tarafindan Almanya'da yaşayan Türklerin aile değerlerini konu alan çalışmada da çalışan kadınların ev hanımı olan kadınlardan cinselliğe bakış, çocuğun değeri, duygusal bağ ve farklı yaklaşımlar puan ortalamalarının yüksek oldu belirtilmiştir. Toplumda sosyalleşme sorumluluğu genellikle anneye verilmektedir. Fakat çeşitli nedenlerle geleneksel Türk aile yapısı değişikliğe uğramaya başlamıştır. Sağlıklı bir toplum için bireylerin sağlıklı bir aile ortamında yetişmesi ve aile merkezli bir bakım felsefesinin benimsenmesi gerekmektedir (Aktaş, Teksöz ve Ocakçı, 2012). Kadınların çalışma hayatında daha çok yer alması, aile içindeki rolleri ve aile değerleri üzerinde değişiklik oluşturabilir. Kadınların iş hayatına atılmasıyla birlikte ekonomik güç elde eden kadının ailedeki rollerinin değişim gösterebileceği ve aile içerisindeki bireylerle etkileşimin azalabileceği düşünülebilir.

Çalı̧̧mada 31 yaş ve daha büyük yaştaki kadınların 31 yaşından küçük yaştaki kadınlara göre daha fazla oranda aileyi geleneksel olarak değerlendirdikleri, çocuk bakımında anneye önem atfettikleri, çocuk yetiştirme rolüne önem verdikleri, ailede demokratik katılım olması gerektiğini düşündükleri, aileyi sosyal ve ekonomik bir yapı olarak algıladıkları, akraba ilişkilerine önem verdikleri ve geniş aileye olumlu baktıkları, aileye duygusal bağlılıkların arttı̆̆1; 31 yaşın altındaki kadınların 31 yaş üstü kadınlara göre daha fazla cinsellikle ilgili konularda serbestlikten yana oldukları, konvansiyonel olmayan değerleri önemsedikleri, eşler arası sadakate önem verdikleri ve aile saadeti için şiddeti meşru gördükleri belirlenmiştir. Acharya ve arkadaşları (2010) tarafından yapılan çalışmada genç kadınların karar alma sürecine katılma olasılığının yaşlı kadınlara göre daha az olduğu belirlenmiştir. Erbil ve Pasinlioğlu'nun (2004) çalışmasında kadınların yaşı küçüldükçe ailede karar verme durumlarında artış olduğu belirlenmiştir. Taylan (2016) toplumda meydana gelen değişimlere benzer şekilde ailenin yapısında, ilişkilerinde ve aile değerlerinde de değişimler yaşanmakta ve bu değişimlerin üniversite gençlerinde görüldüğü geleneksel aile ilişkileri ve ataerkillik yerine daha modern bir aile ilişkisi geliştirdikleri, şiddet, iletişimsizlik sadakatsizlik gibi durumlarda gençler tarafından aile içerisindeki en önemli sorunlar olarak görüldüğü belirlenmiştir. Meydan ve arkadaşlarının (2017) aile değerleri üzerine yaptıkları olgusal bir çalışmada ileri yetişkinlerin, gençlere, orta ve genç yetişkinlere göre gelenek ve göreneklere daha fazla önem verdiği belirlenmiştir. Şahin (2019) çalışmasında 35 yaş altı bireylerin akraba ilişkisi puanları 35-44 yaş grubu bireylerden, 35-44 yaş ve 45 yaş ve üzeri bireylerin cinselliğe bakış puanları 35 yaş altı bireylerden, 35-44 yaş grubu birey- 
lerin kadın rolleri ve şiddet puanları 35 yaş altı bireylerin puanlarından anlamlı düzeyde daha yüksek bulunmuştur. Polat (2020) çalışmasında yaş arttıkça aile anne-çocuk ilişkisi, duygusal bağ değerlerinde azalma ve cinselliğe bakış, kadın rolleri değerlerinde yükselme olduğu belirlenmiştir. Dolayısıyla yaş artıkça çoğu zaman cinsellik konusunda çekincelerinin ortadan kalktığı, ailelerin kimi zaman şiddeti görmezden gelebilecekleri, farklı düşüncelere verilen önemin de arttığ d düşünülebilir.

Çalışmada ilkokul mezun kadınların daha fazla oranda aileyi geleneksel olarak değerlendirdikleri, çocuk bakımında anneye önem atfettikleri, çocuk yetiştirme rolüne önem verdikleri, ailede demokratik katılım olması gerektiğini düşündükleri, aileyi sosyal ve ekonomik bir yapı olarak algıladıkları, akraba ilişkilerine önem verdikleri ve geniş aileye olumlu baktıkları, aileye duygusal bağl11ıkların arttığı; öğrenim düzeyi yükseldikçe kadınları daha fazla cinsellikle ilgili konularda serbestlikten yana oldukları, konvansiyonel olmayan değerleri önemsedikleri, eşler arası sadakate önem verdikleri ve aile saadeti için şiddeti meşru gördükleri belirlenmiştir. Şahin'in (2019) çalışmasında eğitim durumu ön lisans olan katılımcıların kadın rolleri puanı, öğrenim durumu lisans düzeyinde olan katılımcıların puanlarından anlamlı düzeyde daha yüksek olduğu; eğitim durumu ön lisans düzeyinde olan katılımcıların şiddet puanları, öğrenim durumu lisans ve lisans üstü düzeyde olan katılımcıların puanlarından anlamlı düzeyde daha yüksek olduğu saptamıştır. Özyürek ve arkadaşları (2019), yetişkinlerin aile değerlerini inceledikleri çalışmalarında lisans mezunu yetişkinlerin şiddet alt boyut puanlarının ilköğretim mezunlarından daha yüksek olduğunu saptamışlardır. Erbil ve Pasinlioğlu (2004) tarafından yapılan çalışmada eğitim düzeyi artıkça kadınların aile içerisinde alınan kararlarda, karar vermeye katılımlarının da arttığı belirlenmiştir. Bu çalışmalar araştırmanın bulgusunu desteklerken Polat'ın (2020) eğitim durumuna göre aile değerlerinin farklılaşmadığı sonucu bulduğu çalışma ve Demir ve Kök'ün (2012) çalışmalarına katılan ailelerin benzer değerleri benimsediği ve bu benimsenen değerlerin eğitim seviyesine göre anlamlı ölçüde değişmediğini belirlendiği çalışma da araştırma bulgusuyla çelişmektedir. Öğrenim durumu ileri düzey olan kadınların bulundukları çevreden bir süreliğine ayrılarak farklı yerlerde öğrenim gördüğü varsayılarak, farklı çevrelerden farklı görüşlerle karşılaşmış ve bu görüşlerden etkilenmiş olabileceği, öğrenim durumu ilkokul düzeyinde olan kadınların ise hala geleneksel aile yapısını sürdürmek istedikleri düşünülebilirken araştırma bulgusuyla çelişen çalışmalar da dikkate alınırsa eğitim durumunun aile değerini tek başına farklılaştırmadığı da düşünülebilir. 
Çalışmada 11 yıl ve üzeri olan kadınların 1-10 yıllık süreyle evli olanlara göre daha fazla oranda aileyi geleneksel olarak değerlendirdikleri, çocuk bakımında anneye önem atfettikleri, çocuk yetiştirme rolüne önem verdikleri, ailede demokratik katılım olması gerektiğini düşündükleri, akraba ilişkilerine önem verdikleri ve geniş aileye olumlu baktıkları, aileye duygusal bağl11ıkların arttığ1; evlilik süresi 1-0 yıl olan kadınların daha uzun süre evli olanlara göre daha fazla cinsellikle ilgili konularda serbestlikten yana oldukları, konvansiyonel olmayan değerleri önemsedikleri, eşler arası sadakate önem verdikleri ve aile saadeti için şiddeti meşru gördükleri belirlenmiştir. Meydan ve arkadaşları (2017) çalışmalarında evlilik süresi artıkça gelişime ayak uydurmak yerine gelenek ve göreneklere göre bağlı olunmasının öneminin artığ 1 ve en bağlı grubun evlilik süresi 11-20 yıl olan katılımcıların oluşturduğu saptanmıştır. Şahin (2019) çalışmasında 10-14 yıl, 15-19 yıl ve 20 yıl ve üzeri evlilik süresi olan bireylerin 5-9 yıl evlilik süresi olan bireylere göre evliliğe bakış ve kadın rolleri puanları anlamlı derece yüksek bulunmuştur. Araştırmanın sonucuna göre evlilik süresi az olan kadınların evliliğe adapte sürecinde oldukları ve evlilik süresi artıkça aile içi değerlerin daha çok benimsendiği düşünülebilir.

Çalışmada çocuk sayısı fazla olan kadınların daha fazla oranda aileyi geleneksel olarak değerlendirdikleri, çocuk yetiştirme rolüne, akraba ilişkilerine önem verdikleri ve geniş aileye olumlu baktıkları, aileye duygusal bağll1ıkların arttığı; çocuğu olmayan veya az çocuklu kadınların daha fazla cinsellikle ilgili konularda serbestlikten yana oldukları, konvansiyonel olmayan değerleri önemsedikleri ve aile saadeti için şiddeti meşru gördükleri belirlenmiştir. Alan yazında bu sonuçla kısmen benzerlik gösteren çalışmalar mevcuttur. Özyürek ve arkadaşları (2019) tarafından yapılan çalışmada üç ve daha fazla çocuğu olan yetişkinlerin cinselliğe bakış alt boyut puanı tek çocuğu olanların puanına göre daha yüksek bulunmuştur. İki çocuğa sahip yetişkinlerin anne-çocuk ilişkisi puanı diğerlerinden düşük, hiç çocuğu olmayanların akraba ilişkileri puanı ise bir çocuğu olanların puanına göre anlamlı düzeyde daha düşük bulunmuştur. Şahin (2019) çalışmasında akraba ilişkileri, anne-çocuk ilişkisi, evliliğe bakış, geleneksel aile değerleri, kadın rolleri, farklı yaklaşımlar alt boyut puanlarının çocuk sayısına göre anlamlı bir değişiklik gösterdiği belirtilmiş. İki çocuk ve üç ve daha fazla çocuk sahibi olan bireylerin aile değerleri ölçek puanları, çocuk sahibi olmayan bireylerden daha yüksek bulunmuştur. Bu çalışmalar benzerlik gösteren çalışmalarken, Erbil ve Pasinlioğlu, (2004) tarafından çocuk sayısının kadınların ailelerinde alınan kararlarda, karar verme sürecine katılmasında önemli bir etkinin olmadığını belirttiği çalışma, araştırma bulgusuyla kısmen 
çelişmektedir. Araştırmamızda böyle bir sonucun çıkması katılımcıların evli kadınlardan oluşması ve büyük çoğunluğun çocuk sahibi olmasıyla ilişkilendirilebilir. Dolayısıyla çocuk sahibi olmanın tek başına aile değerleri üzerinde etkili olmadığı düşünülebilir.

Genel olarak ortaya çıkan sonuçlar ise şu şekildedir: Kırsalda ikamet eden, çalışmayan/ev hanımı, öğrenim düzeyi düşük, evlilik süresi 11 yıl ve üzeri, çocuk sayısı fazla olan kadınlar geleneksel aile değerlerini korumakta, çocuk bakımı konusunda anneye daha fazla önem atfetmekte, ailede çocuk yetiştirme rolüne daha fazla önem vermekte, ailede karar alma sürecine demokratik katılımdan yana olmakta, aileyi daha çok sosyal ve ekonomik bir yapı olarak algılamakta, akraba ilişkilerine önem vermekte ve geniş aileye olumlu bakmakta, aileye duygusal bağları daha fazla olmaktadır. Kentte ikamet eden, öğrenim düzeyi yüksek, evlilik süresi 10 ve daha az, çocuğu olmayan veya az çocuklu kadınlar ise cinsellikle ilgili konularda daha fazla serbestlikten yana olmakta, konvansiyonel olmayan değerleri daha fazla benimsemekte, eşler arası sadakate daha fazla önem vermekte ve aile saadeti için şiddeti meşru görme düşünceleri daha baskın olmaktadır.

Aile değerleri hem bireyin kendisi hem de toplum için vazgeçilmezdir. Kırsal alanda ve kentte yaşıyor olmak, aile değerlerini etkilemektedir. Fakat teknolojinin insanların yaşamına girmesiyle pek çok bilgiye internet aracılığıyla erişilmesi, yaşam standartlarının değişmesi, resmi ve sivil toplum kuruluşlarının kadın hakları veya aile içi şiddet benzeri konularda farkındalık çalışmaları, toplumdaki tüm bireylerin eğitim, sağlık gibi hizmetlere erişebilmeleri veya haklarından haberdar olmalarına katkı sunmaktadır. Bu nedenle, kırsalda geleneksel aile yapısının veya geleneksel bakış açısının giderek azaldığı söylenebilir. Değişimlerin süreklilik gösterdiği toplumlarda aile değerleri değişmekte ya da aile değerlerine yaklaşım farklılaşmakta, bu farklılaşmada toplumsal değişmelerin yanında bireyin yaşam koşulları ve kişisel özellikleri rol oynamaktadır. Elde edilen sonuç yaşanılan bölgenin kırsal veya kent olması, kadınların çalışıp çalışmama durumu, öğrenim düzeyi, evlilik süresi ve çocuk sayıları değişkenlerinin aile değerlerinde farklılık oluşturduğunu göstermektedir. Aile yapısının ve dolayısıyla toplumun yapısının korunmasında, aile değerlerinin önemi dikkate alınarak aşağıdaki öneriler geliştirilmiştir:

Aile değerlerinin yaşatılması görevi ilk başta toplumun en küçük birimi olan aileye düşmektedir. Anne-babaların bu görevin bilincinde olması çocuklarına değer aktarımı konusunda faydalı bir rol model ve aile değerlerine ilişkin ge- 
reken bilgiye sahip olmaları önemlidir. Çocukluktan itibaren bireylere ailenin değerli olduğu ve aile değerlerinin önemli olduğu öğretilmelidir. Bunun için başta anne-babalar olmak üzere ilgili tüm bireylerin, çocuklara olumlu rol model olması gerektiği bilinciyle hareket etmesi önerilebilir.

Toplumunun en küçük ve temel birimi ailedir, ailenin varlığını sürdürebilmesi ise aile değerlerinin varlığıyla mümkündür. Bu nedenle, eğitim ve sağlık çal1şanları veya aileyle ilgili diğer tüm kurumların yürüttüğü aile eğitimi çalışmalarında aile değerleri konusuna yer vermeleri, hatta öncelikli konular arasında ele almaları önerilebilir. Yapılacak eğitsel çalışmaların erken çocukluk, okul çağı, yükseköğretim ve evlilik öncesinden itibaren toplumun her yaştan ve her kesiminden bireylere yönelik planlanıp yürütülmesi önerilebilir. Aile değerlerinin nesilden nesile aktarıldığı düşünüldüğünde, aileler kendileri için hangi değerlerin önemli olduğuna ve çocuklarının hangi değerleri kazanmasını istediklerine karar vermeleri, bu doğrultuda gerekli çabayı sarf etmeleri gerekmektedir. Aile için neyin önemli olup neyin olmadığı, çocuklara küçük yaşlardan itibaren öğretilmelidir.

Aile değerlerinin belirlenmesinde bireylerin bakış açıları önemlidir. Ailedeki rol ve statülerin daha demokratik bir yaklaşımla ele alınabilmesi için özellikle kadınların öğrenim düzeyinin yüksek olması ve çalışma yaşamında aktif olarak yer almasına yönelik farkındalık çalışmaları yapılabilir. Aile içi şiddetin meşru görülmesi, aile bağlarının korunması gibi konuları ele alan çalışmaların farklı değişkenler açısından ele alınması önerilebilir.

$\mathrm{Bu}$ çalışmada yalnızca kadınların çalışma grubuna dahil edilmiş olması, çalışmanın sınırlılığı olarak ele alınabilir. Benzer çalışmalarda kadın ve erkeklerin bir arada ele alındığı çalışma grubu oluşturulabilir. Ayrıca kadınların aile değerlerinin, sosyal statülerinin, yaşadıkları yerin, kendi çocuklarının aile değerlerini veya değerlerin kuşaklar arası aktarımını nasıl etkilediği konusunda farklı değişkenler ele alınabilir. $\mathrm{Bu}$ araştırma betimsel bir çalışmadır, deneysel çalışmalarla eğitim programlarının etkilerine bakılabilir.

\section{Kaynakça}

Acharya, D. R., Bell, J. S., Simkhada, P., Van Teijlingen, E. R. \& Regmi, P. R. (2010). Women's autonomy in household decision-making: a demographic study in Nepal. Reproductive health, 7(1), 15. https://doi.org/10.1186/17424755-7-15 
Ajah, L. O., Iyoke, C. A., Nkwo, P. O., Nwakoby, B. \& Ezeonu, P. (2014). Comparison of domestic violence against women in urban versus rural areas of Southeast Nigeria. International Journal of Women's Health, 6, 865. Doi: 10.2147 / IJWH.S70706

Akın, M. H. \& Aydemir, M. A. (2007) Üniversitede okuyan kız öğrencilerin cinsiyet rolü tutumları bağlamında aile ve evlilik kurumlarına bakışları (Selçuk Üniversitesi Örneği), Selçuk Üniversitesi, Edebiyat Dergisi, 18, 43-60.

Albayrak, A. (2017). Ziya Gökalp’te kadın ve aile. Social Sciences Research Journal, 6(4), 244-252.

Aktaş, G. (2015). Türkiye'de aile sosyolojisi çalışmalarına genel bir bakış /A general overinew on sociology of family in Turkey. Sosyoloji Konferanslarl, (52), 419. https://doi.org/10.18368/IU/sk.53365

Aktaş, E., Teksöz, E. \& Ocakçı, A.F. (2012). Ailede kadının değişen rolünün çocuk sağlığına etkisi ve aile merkezli bakımın önemi. Ege Üniversitesi Hemşirelik Fakültesi Dergisi, 28(1), 73-80.

Aktepe, V. \& Yel, S. (2009). İlköğretim öğretmenlerinin değer yargılarının betimlenmesi: Kırşehir ili örneği. Journal of Turkish Educational Sciences, 7(3), 607-622.

Altun, S. A. (2003). Eğitim yönetimi ve değerler. Değerler Ĕgitimi Dergisi, 1(1), 7-17.

Arda, M.A. (2018). Aile değerlerinin ve mizaç-karakter özelliklerinin alkol kullanımına etkisi. (Yüksek lisans tezi). İstanbul: Işık Üniversitesi.

Arends-Tóth, J. \& Van de Vijver, F. (2009). Cultural differences in family, marital, and gender-role values among immigrants and majority members in the Netherlands. International Journal of Psychology, 44(3), 161-169. https:// doi.org/10.1080/00207590701545676

Arıkan, G. (1988). Kirsal kesimde kadın olmak. Hacettepe Üniversitesi Edebiyat Fakültesi Dergisi, 5(2), 1-16.

Arpacı, F. \& Ersoy, A. F. (2007). Kadının çalışmasının ailenin yaşam kalitesine etkisinin incelenmesi. Sosyal Politika Çalışmaları Dergisi, 11(11), 41-50.

ASAGEM, T. B. (2010). Türkiye'de aile değerleri araştırması. Ankara: T.C. Aile ve Sosyal Araştırmalar Genel Müdürlüğü yayınları.

Atkinson, A. M. (1994). Rural and urban families' use of child care. Family Relations, 16-22. https://doi.org/10.2307/585137

Bolat, Y. (2016). Sosyal değerleri ve değerler eğitimini anlamak. Akademik sosyal araştırmalar dergisi, 4(29), 322-348.

Bozdemir, N. \& Özcan, S. (2011). Cinselliğe ve cinsel sağlığa genel bakış. Turkish Journal of Family Medicine and Primary Care, 5(4), 37-46. 
Castro, F. G., Stein, J. A. \& Bentler, P. M. (2009). Ethnic pride, traditional family values, and acculturation in early cigarette and alcohol use among Latino adolescents. The Journal of Primary Prevention, 30 (3-4), 265-292. https:// doi.org/10.1007/s10935-009-0174-Z

Çağ, P. \& Yıldırım, İ. (2013). Evlilik doyumunu yordayan ilişkisel ve kişisel değişkenler. Turkish Psychological Counseling and Guidance Journal, 4(39), 13-23.

Çakmak, F. (2009). 2000'li yıllarda Türkiye'de muhafazakâr nitelikli gazetelerde kadın kimliğinin temsili (Yüksek Lisans Tezi). Konya: Selçuk Üniversitesi.

Demir, K. \& Kök, A. (2012). Students' families and family values. Procedia-Social and Behavioral Sciences, 47, 501-506. https://doi.org/10.1016/j.sbspro.2012.06.688

Dewanggi, M., Hastuti, D. \& Herawati, T. (2015). The influence of attachment and quality of parenting and parenting environment on children's character in rural and urban areas of Bogor. Jurnal Ilmu Keluarga \& Konsumen, 8(1), 20-27. https://doi.org/10.24156/jikk.2015.8.1.20

Dillon, H. N. (2005). Family Violence and Divorce: Effects on Marriage Expectations. State University. Electronic Theses and Dissertations.

Duman, M. (2016). Çocuğun değeri: Adana araştırması (Yüksek Lisans Tezi). Çağ Üniversitesi, Sosyal Bilimler Enstitüsü, Adana.

Ekşi, H., Demirci, İ., Yıldız, C. \& Ekşi, F. (2015). Almanya'da yaşayan Türk göçmenlerin aile değerleri. Değerler Ĕ̆itimi Dergisi, 13(29), 41-82.

Ellena, R. \& Nongkynrih, K. A. (2017). Changing gender roles and relations in food provisioning among matrilineal Khasi and patrilineal Chakhesang Indigenous rural People of North-East India. Maternal \& child nutrition, 13, e12560. https://doi.org/10.1111/mcn.12560

Erbil, N. \& Pasinlioğlu, T. (2004). Kadının ailede karar vermeye etkisi. Anadolu Hemşirelik ve Sağlık Bilimleri Dergisi. 7(2), 1-11.

Erkut, Z., Balcı, S. \& Yıldız, S. (2017). Tarihsel süreç içinde çocuk. Çocuk ve Medeniyet, 2(3), 17-28.

Erol, P. Ö. \& Aloğlu, E. (2017). Çocuğun değeri ve aile değişimi: Türkiye'den otuz yıllık bir portre. Sosyoloji Dergisi, (35), 77-101.

Gönüllü, M. \& İçli, G. (2001). Çalışma yaşamında kadınlar: aile ve iş ilişkileri. C.Ü. Sosyal Bilimler Dergisi, May1s 2001 Cilt: 25 No: 1 81-100.

Hayward, M. \& Zhang, Z. (2006). Gender, the marital life course, and cardiovascular disease in late midlife. Journal of Marriage and Family, 68(3), 639-657. https://doi.org/10.1111/j.1741-3737.2006.00280.x 
http://spokanecares.org/family-values-spokane.php. (2021). Family values (Erişim Tarihi: 09.06.2021).

http://www.tdk.gov.tr/ (Erişim Tarihi: 25.12.2020).

Kandır, A. \& Alpan, U. Y. (2008). Okul öncesi dönemde sosyal-duygusal gelişime anne-baba davranışlarının etkisi. Sosyal Politika Çalışmaları Dergisi, 14(14), 33-38.

Kara, B. (2018). Türkiye' de aile yapısının değişimine etki eden dinamikler. Karadeniz-Blacksea-Черное море, (40), 374-385.

Keskin, E. (2016). Kentleşme sürecinde ailenin değişimi: Bursa'da bir alan araştırması. Paradoks Ekonomi Sosyoloji ve Politika Dergisi, (Özel Say1), 158-189.

Kır, İ. (2011). Toplumsal bir kurum olarak ailenin işlevleri. Elektronik Sosyal Bilimler Dergisi, 10 (36), 381-404.

Kızıler, H. \& Canikli, İ. (2013). Değerler Ĕ̆itimi. Ankara: Akademikus.

Kömürcü, P., Demirci, D., Yıldız, D. \& Gün, A. (2014). Türkiye’deki hemşirelik dergilerinden cinselliğe bakış: Bir literatür incelemesi. Hemşirelikte Eğitim ve Araştırma Dergisi, 11(1), 9-17.

Meydan, H., Aybey, S. \& Dikmen, M. (2017). Zonguldak'ta hayatın anlamı ve aile değerleri üzerine olgusal bir araştırma, Zonguldak Bülent Ecevit Üniversitesi Yayınları, No: 23.

Özbay, F. (2014). Akrabalık ve komşuluk ilişkileri. Türkiye'de Aile Yapısı Araştırmalart Tespit ve Öneriler, 56-87.

Özkiraz, A., Arslanel, M. N. \& Şengül, T. (2016). Gaziosmanpaşa üniversitesi öğrencilerinin aile kurumuna bakışı. Atatürk Üniversitesi İktisadi ve İdari Bilimler Dergisi, 30(2), 243-268.

Özyürek, A., Özpınar, H., Okçu, A., Kabakuş, B.S., Öksüzoğlu, Ş., Fikir, S., Akarsu, Ş., Karaoğlu, M., Yağımlı M. A. \& Şahin, H. (2019). Yetişkinlerin aile değerlerinin kişisel bazı değişkenlere göre incelenmesi. IBAD Sosyal Bilimler Dergisi, 2019 (1) 121-134.

Polat, Ş.C. (2020). Üniversite öğrencilerinin kişilik özellikleri ile aile değerleri arasındaki ilişkinin incelenmesi (Yüksek lisans tezi). İstanbul: İstanbul Sabahattin Zaim Üniversitesi.

Scanzoni, J. \& Arnett, C. (1987). Policy implications derived from a study of rural and urban marriages. Family Relations, 430-436. https://doi.org/10.2307/584496

Schwartz, S.H. (2006), Basic human values: an overview, The Hebrew University of Jerusalem, Jerusalem.

Sönmez, V. \& Alacapınar, F. (2011). Bilimsel araştırma yöntemleri. Ankara: Anı. 
Struch, N., Schwartz, S. H. \& Van Der Kloot, W. A. (2002). Meanings of basic values for women and men: Across-cultural analysis. Personality and social psychology bulletin, 28(1), 16-28. https://doi.org/10.1177\%2F0146167202281002

Şahin, E. (2019). Farkl1 sosyo-kültürel yapılardan gelmiş evli bireylerin aile değerleri ve aile bütünlük duygusu arasındaki ilişkinin incelenmesi (Yüksek lisans tezi). İstanbul: İstanbul Sabahattin Zaim Üniversitesi.

Taylan, H. H. (2016). Sakarya Üniversitesi öğrencileri penceresinden Türkiye'de aile içi sorunlar. In ICPESS (International Congress on Politic, Economic and Social Studies) (No. 1), 459-474.

Tutar, H. (2007). Kırgızlarda akrabalık terminolojisi ve akrabalık ilişkileri. Hacettepe Üniversitesi Türkiyat Araştırmaları (HÜTAD), (6), 155-169.

Türkiye Cumhuriyeti Anayasası. (2021). 4 Ocak 2021 tarihinde https://www. mevzuat.gov.tr/\#anayasai adresinden erişildi. 2709 no'lu 18/10/1982 tarihli kanun. 9/11/1982 Sayılı Resmî Gazete. 5(22), 3.

Tüzer, V. (2011). Internet, Siberseks ve Sadakatsizlik/Internet, Cybersex and Infidelity. Psikiyatride Guncel Yaklasimlar, 3(1), 100-116.

Yapıc1, Ş. (2010). Türk toplumunda aile ve eğitim ilişkisi. Turkish Studies, 5(4), 1544-1570.

Yazıcı, E, (2019). Aile değerleri ile aile yılmazlı̆̆ı arasındaki ilişkinin incelenmesi (Yüksek lisans tezi). İstanbul: İstanbul Üniversitesi.

Yazıcı, M. (2014). Değerler ve Toplumsal Yapıda Sosyal Değerlerin Yeri. Firat University Journal of Social Sciences/Sosyal Bilimler Dergisi, 24(1), 209-223. 
Extended Abstract

\section{Comparison of Family Values of Women Living in Rural and Urban Areas}

Arzu ÖZYÜREK, Professor.

Karabük Üniversitesi, Faculty of Health Science, Karabük / Turkey.

a.ozyurek@karabuk.edu.tr

https://orcid.org/0000-0002-3083-7202

Ayşenur AYDIN, Corresponding Author, Specialist.

Karabük University, Karabük / Turkey.

aydn.aysenr@gmail.com

https://orcid.org/0000-0001-6217-4135

Article Type: Research Article

https://doi.org/10.34234/ded.899968

Received Date: 07.04 .2021

Accepted Date: 11.06 .2021

Published Date: 25.06.2021

\section{Introduction}

The foundation of society is family, and societies need values to exist and maintain their existence. In general terms, value can be defined as an intangible measure that is used to express the importance of anything, a high and useful worth. It is a real measure of behavior shared and agreed upon by most people (Kızıler\&Canikli, 2013). The important feature that distinguishes values from each other is the direction of the values, the type of goal they express. Values, in general, are expressed as desired, transformational goals with changing importance, which provide benefit as guiding principles in the life of the individual (Struch, Schwartz\&Van Der Kloot, 2002). Traditional family values, perception 
of sexuality, mother-child relationship, worth of the child, decision-making processes, perception of marriage, women's role, different approaches, socio-economic value, family relations, emotional bond, and domestic violence can be discussed within the scope of family values (Ekşi et al., 2010).

One of the elements that make up the family is women, who have important roles in society at every stage of social life. However, their roles and statutes change for various reasons (Albayrak, 2017). Living in rural and urban areas may be one of the factors affecting this situation. The vast majority of women living in rural areas work in agriculture, and sometimes their work or what they produce is ignored. Although women who live in rural areas have equal rights before the law with those who live in the city, it can be said that they are more oppressed than those who live in the city due to a low level of education or lack of economic independence. Education and participation in the labor force are higher in cities. In rural areas, the patriarchal family structure is stronger, while the age of marriage and the level of divorce is lower (Arikan, 1988). The role and status of women within the family or society in rural and urban areas is closely related to conditions such as the diversity of their living means and their ability to access services such as education, health, etc. It can be said that the value given to women in the family and the family values of women are also affected by this situation.

When the studies on family values are examined, it is seen that there are studies such as the research conducted by the Republic of Turkey General Directorate of Family and Social Researches (2010), investigating the family perception of media professionals and the media; students' families and family values (Demir and Kök, 2012); female university students' perception of institutions of family and marriage within the context of gender role manners (Akın\&Aydemir, 2007); family values of Turks living in Germany (Ekşi et al., 2015); university students' perception of the family institution (Özkiraz et al., 2016); the effects of family values on alcohol consumption (Arda, 2018); family values of adults (Özyürek et al., 2019); examining the relationship between family values and family resilience (Yazıc1, 2019); policy implications for rural and urban marriages (Scanzoni\&Arnett, 1987); examining the relationship between university students' personalities and family values (Polat, 2020).

In these studies, different study groups' views on family values or some variables related to family values were discussed. However, in this study, it is aimed to examine the family values of married women residing in rural areas and city centers by comparing them based on some personal variables.

The study sought answers to the following questions: 
- Is there a difference in family values of rural and urban women according to age, education level, and working status?

- Is there a difference in the family values of rural and urban women according to the duration of the marriage and the number of children?

\section{Method}

\section{Research Model}

The study was designed quantitatively. The study is in the descriptive survey model since it is being tried to determine the perspective of the mothers on their current family values as they exist (Sönmez\&Alacapınar, 2011).

\section{Study Group}

The study group consisted of a total of 144 married women, 60 women residing in the village and 84 women residing in the city center, who could be reached through the easily accessible sampling method. The criteria for inclusion in the study group were that the women resided in the village or in the city center.

\section{Data Collection Tools}

For the collection of data, The Personal Information Form was used, which was prepared by the researchers and questioned participants' place of residence, age, education status, employment status, marriage duration/year and number of children. The family Values Scale was used to determine family values.

\section{Data Collection and Analysis}

The permission of Karabük University Social and Humanities Researches Ethics Committee was obtained for the study. While collecting the data, the women in the countryside were read the scale's bullet points and their answers were marked or they were asked to fill in the written scale form. Women in the city center were contacted online, and they were asked to fill in the scale bullet points online. The normality distribution of the data was examined with the Kolmogorov Smirnov Test and it was seen that there was no normal distribution according to the variables, accordingly non-parametric tests were used in the analysis of the data. Mann Whitney $U$ test was used for binary variables and Kruskal Wallis $\mathrm{H}$ test was used for three or more variables. The significance value was taken as .05 . 


\section{Findings}

The general results of the study are as follows: Women who live in rural areas, do not work/are housewives, have a low education level, have a marriage duration of 11 years or more and have more children maintain traditional family values, and attribute more importance to the mother about child care. They attach more importance to the role of raising children in the family, favor democratic participation in the decision-making process in the family, perceive the family more as a social and economic structure, attach importance to family relations, have a positive view of the extended family, and have more emotional ties to their family. While women who reside in the city, have a high education level, have a marriage duration of 10 years or less, and have no or fewer children are in favor of more freedom in sexual matters and they adopt unconventional values more, attach more importance to loyalty between spouses and have more dominant thoughts of finding violence permissible for family happiness.

\section{Result and Discussion}

Family values are indispensable for both the individual and the society. Living in rural and urban areas affects family values. However, with the introduction of technology into people's lives, having access to a lot of information via internet, changing of the life standards, awareness-raising activities by official and non-governmental organizations on issues such as women's rights or domestic violence contribute to the access of all individuals of the society to services such as education and health, or to be aware of their rights. For this reason, it can be said that the traditional family structure or traditional perspective is gradually decreasing in rural areas. In societies where the changes are continuous, family values change or the approaches to family values differ. In addition to social changes, the living conditions and personal characteristics of the individual play a role in this differentiation. The results show that the variables of residing in rural or urban areas, women's employment status, education level, marriage duration, and their number of children make differences in their family values.

In literature, some studies support the results obtained from the study and have different results. In his study on the change of the family during the urbanization process, Keskin (2016) found that the perceptions on making decisions together in the family-decision-making process are higher in the villages than in the cities. In the study conducted by Scanzoni and Arnett (1987), it was stated that women and men living in rural areas were less educated than those living in the city, and their gender role preferences were more traditional. In the study 
conducted by Erbil and Pasinlioğlu (2004), it was determined that as the level of education increased, women's participation in the decisions made within the family also increased. In general, the Turkish family structure began to change. For a healthy society, individuals should be brought up in a healthy family environment and a family-centered care philosophy should be adopted (Aktaş, Teksöz\&Ocakçı, 2012). The fact that women are more involved in working life may change their roles in the family and family values.

\section{Suggestions}

The smallest and most fundamental unit of the society is family, and survival of the family is possible with the existence of family values. For this reason, it can be suggested that education and health professionals or every other institution related to the family should include the issue of family values in family education studies they conduct, and even consider it among the priority issues. It can be suggested that educational studies be planned and carried out for individuals from all ages and all parts of society, starting from early childhood, school age, higher education, and before marriage. The fact that only women were included in the study group in this research can be considered as a limitation of the study. In similar studies, a study group can be formed in which women and men are handled together. In addition, different variables can be discussed in terms of how women's family values, social status, and where they live affect the family values of their children or the transmission of values between generations. This research is a descriptive study, the effects of educational programs can be examined with experimental studies.

Etik Beyan / Ethical Statement: Bu çalışmanın hazırlanma sürecinde bilimsel ve etik ilkelere uyulduğu ve yararlanılan tüm çalışmaların kaynakçada belirtildiği beyan olunur. / It is declared that scientific and ethical principles have been followed while carrying out and writing this study and that all the sources used have been properly cited.

Finansman / Funding: Yazarlar, bu araştırmayı desteklemek için herhangi bir dış fon almadıklarını kabul ederler. / The authors acknowledge that they recevied no external funding in support of this research.

Yazar (lar) / Author (s): Ayşenur AYDIN, Arzu ÖZYÜREK

Yazar Katkıları / Author Contributions: Ayşenur AYDIN (\%50), Arzu ÖZYÜREK (\%50)

Çıkar Çatışması / Competing Interests: Yazarlar, çıkar çatışması olmadığını beyan ederler. / The authors declare that they have no competing interests. 